DEUİFD XLVII/2018, ss. 225-261.

\title{
İSLAM HUKÛKUNDA CİNSEL DOKUNULMAZLIĞA KARŞI İŞLENEN HETK-İ IRZ (TECAVÜZ) SUÇUNUN CEZASI VE KUR'AN CEZA İLKELERİ AÇISINDAN DEĞERLENDİRMESİ
}

\author{
ÖZ
}

Adem YILDIRIM*

İnsan bedenine karşı işlenen en ağır suçlardan biri hetk-i 1rz (tecavüz) suçudur. İslam hukuku tecavüz suçunu müstakil bir suç türü olarak değil, zina suçu kapsamında ele almıştır. Tecavüz fiiline ceza müeyyidesi olarak had cezası öngörmüştür. Aynı zamanda faile birtakım tazminatlar da yüklemiştir.

$\mathrm{Bu}$ suça Osmanlı kanunnamelerinde ağırlaştırılmış bir ceza müeyyidesi olarak hadım cezası öngörülmüştür. Hadım cezası Tanzimatla birlikte yerini hapis cezasına bırakmıştır. Türk Ceza Hukuku'nda tecavüz fili müstakil bir suç türü olarak değil, cinsel dokunulmazlığa karşı suçlar başlığı altında mütalaa edilmiştir. Günümüzde bazı Avrupa devletleri tecavüz suçuna Osmanlı kanunnamelerinde olduğu gibi hadım cezası vermektedir. Fakat Osmanlı kanunnamelerindeki cerrahi hadım cezası, burada yerini kimyasal hadıma bırakmıştır. Tecavüze maruz kalan mağdurun düştüğü zor durum dikkate alındığında, Osmanlı Kanunnamelerinde olduğu gibi bu suçun cezası cerrâhî kastrasyon (hadım) olmalıdır. Kur'an ceza ilkeleri dikkatlice incelendiğinde tecavüz suçunun cezasının cerrâhî kastrasyon olması gerektiği savunulabilir.

Anahtar Kelimeler: İslam Hukuku, Cinsel İstismar, Irza Tecavüz, Hadım, Kastrasyon.

\section{PENALTY OF CRIME HETK-I IRZ (RAPE) THAT IS PROCESSED \\ AGAINST SEXUAL IMMUNITY AND EVALUATION FOR QURAN PENALTY PRINCIPLES IN THE ISLAMIC LAW}

\section{ABSTRACT}

One of the most serious crimes against the human body is a "hetk-i 1rz" (rape) crime. Islamic law is not the crime of rape as a separate type of crime has

* Dr. Öğr. Üyesi, Kırıkkale Üniversitesi İslami İlimler Fakültesi F1kıh Anabilim Dalı (Kir1kkale University Faculty of Islamic Sciences Defartment of Fiq1h Kir1kkale, Turkey), ademyildirim@hotmail.com, ORCID ID orcid.org/0000-0002-7020-8099

Makalenin Hakemlere Gönderiliş Tarihi : 07/05/2018

Makalenin Hakemlerden Geliș Tarihi : 05/07/2018 
addressed the scope of adultery. Rape as a criminal sanction the actual penalty had been predicted. At the same time the offender has also install some compensation.

This crime Ottoman rule books castration as a punishment for aggravated criminal sanctions envisaged. Tanzimat replaced with castration punishment has left the prison. Rape in the Turkish Penal Code is not actually a separate type of crime has been transcendental under the title crimes against sexual immunity. Today, as some European states to the Ottoman rule books rape give scastration punishment. But surgicalca stration punishment in the Ottoman Empire was replaced here with chemical castration. Considering the difficult situation where rape victim sex posed to the fall of the eunuchs said to coincide with the principles of the Qur'an criminal penalties in the Ottoman Empire.

Keywords: Islamic Law, Denominations, Sexual Attack, Eunuch, Castration

\section{GİRİ̧}

\section{Hetk-i Irz (Tecavüz) Suçunun Kavramsal Çerçevesi}

İslam hukuk literatüründe tecavüz fiili müstakil bir suç türü olarak değerlendirilmeyip, zina fiili kapsamında ele alınmıştır. Fikıh literatüründe tecavüz, bir erkeğin güç kullanarak zorla bir kadınla zina etmesi şeklinde tarif edilmektedir. ${ }^{1}$ Tecavüz fiiline ceza olarak büyük oranda zinaya verilen had cezası öngörülmüştür. Şartları oluşmadığından had cezası uygulanamadığı durumlarda bu fiil için had cezası yerine tâzir cezasının verilmesi benimsenmiştir. İslam hukukunda tecavüz filinin müstakil bir suç türü olarak değerlendirilmemiş olması, bu fiile ilişkin ortak bir kavram üzerinde uzlaşıyı olumsuz yönde etkilemiş olsa da tecavüz filli için kullanılan birtakım terkip ve isimlere kaynaklarda rastlamak mümkündür. Kadim fikıh külliyatında tecavüz filli için ifd $\hat{a}^{2}$

Ebu Bekr İbn Mes'ûd el-Kasânî, Bedâiu's-Sanâî fì tertîb'i-Şirâî (b.y.: Dâru'l-Hadîs, 1986), 7: 319; Ömer Nasuhi Bilmen, Hukuke İslâmiyye ve Istılâhat-r Frkbiyye Kâmusu, (İstanbul: Bilmen Yayınevi, 1967), 3: 197.

2 Ebu'l-Fadl Cemâluddîn Muhammed İbn Manzûr, Lisânu'l-Arab (Kâhire: Dâru'lMeârif, 1119), "fedâ" md., 3430-3431; İbn Ahmed Muhammed ez-Zürkânî, Şerhu'zZurkân̂̂ Mubtasar-u Seyyidi Hal̂̀l (Beyrut: Daru'l-Kütübu'l-İlmiyye, 2002), 8: 69; Muhammed Âliș, Șerb'u Menbi'l-Celîl Alâ Mubtasari'l-Allâme Halîl, (b.y.: Dâr-u Mesâdir, ts.), 4: 414; el-Kasânî, Bedâiu's-Sanâî fî̀ Tertîb'i-Şirâî, 7: 319; Mahmud 
iğtisâab', ez-zina bi'l-gahr, müstekrehe ale'z-zinât gibi kavramlar kullanilır; daha sonralar1 cebr ile tasarruf, gasben ahz, cebren fiili șen'î, cebren zina gibi kavramlar kullanılmaya başlamıştır. Yakın dönemlere gelindiğinde ise Osmanlı kanunnamelerinde tecavüz fillini karşılamak için "namus perdesini yırtma I rrza saldirma" anlaminda "heteke" ve "1rz" kelimelerinin tertibiyle oluşturulan "betk-i iræ," kavramı kullanılmaya başlanmıştır. Günümüz İslam hukukçuları bu fiilin Arapça karşıllğı olarak "iğtisâb" kavramını kullanmaktadırlar. ${ }^{8}$ Tecavüz fiilini karşılamak için bu çalışmada "betk-i ıř" kavramı tercih edilmiştir.

İslam hukukunda tecavüz fiilinin mağdur üzerindeki fiziki tahribâtını ifade etmek için "ifdâ" kavramı kullanılmaktadır. Ayrıca ifdâ kavramı kar1-koca arasındaki cinsel ilişkide kadında meydana gelecek olası yaralanmaları veya müessir fill sonucu harici bir etkenin/cismin kadının fercine isabet etmesi sonucu oluşacak yaralanmaları da kapsamaktadır. ${ }^{9}$ Buna göre, klasik fikıh kaynaklarında ifdâ; maddi darbe veya tecavïzün, idrar ve cinsî temas yolunu yurtıp tek yol hâline getirmesi veya ferc ile dübür arasindaki et perdesinin yurtılmasi şeklinde bir sonuc meydana getirmesi ${ }^{10}$ şeklinde tarif edilmektedir.

Abdurrahman Abdu'l- Mun'im, Mu'cem el-Musdalebât ve'l-elfäz?l'-Fıkhiyye (b.y.: Dâru'lFazîle, ts.), 1: 250-251.

3 Abdu'l-Mun'im, el-Musdalebât, 1: 240; İbn Manzur, Lisânül-Arab, "kerih" md., 3865.

4 Şemsiddîn es-Serahsî, el-Mebsud (Beyrut: Dâru'l-Mârife, ts.), 4: 53; Sâlim el-İmrâni'şŞâfiî el-Yemenî, el-Beyân fi Mežhebi'l-Imâm eș-Şâfî̀ (Beyrut: Dâru'l-Minhâc, 2000), 12: 360.

5 İbn Manzur, Lisânïl-Arab, "heteke” md., 4612.

6 İbn Manzur, Lisânü'l-Arab, "areze” md., 2887.

7 Ahmet Akgündüz, Mukayeseli İslam ve Osmanl Hukuku Külliyat (Diyarbakır: Dicle Üniversitesi Hukuk Fakültesi Yayınları, 1986), 864-865.

8 Sabri Erturhan, "Fıkhî Açıdan Nitelikli Cinsel Saldırı (Irza Geçme)". C.Ü. İlahiyat Fakültesi Dergisi, 2012, cilt 16, sayı. 2, 27.

9 İbn Manzur, Lisânül'-Arab, “fedâ" md., 3430-3431; Kasânî, Bedâiu's-Sanẩ, 7: 319.

10 Zürkânî, Şerbu'z-Zurkânî, 8: 69; Âliş, Şerb’u Menbi'l-Cellil, 4: 414; Kasânî, Bedâiu'sSanẩ, 7: 319; Şamil Dağcı, İslam Cez̧â Hukukunda Şahıslara Karşı Müessir Füller (Ankara: Diyanet İşleri Başkanlığı Yayınları, 1996), 213; Abdu'l-Mun'im, elMusdalebât, 1: 250-251. 
İslam hukukunda hetk-i 1rz filinin cezası olarak haddin yanı sıra diyet öngörülmektedir. Klasik fikıh külliyatında hetk-i 1rz fiiline verilecek had ve diyetin çeşit ve kapsamı ilgili eserlerin farklı bölümlerinde yer almaktadır. Buna göre, hetk-i 1rz filine verilecek had, "hudûd" bölümünün "zina" alt başlı̆g altında ele alınırken; söz konusu fiil için öngörülen diyet, "diyât" başlığ1 altında işlenmektedir. İslam hukuk mezhepleri genelde hetk-i 1rz fiilinin diyetini tespit ederken müessir fiilin mağdura verdiği fizikî zararın ağırlı̆̆ını esas almışlardır.

İslam hukukuna göre ikrah altında hetk-i 1rz filine maruz kalan kişinin herhangi bir hukuki sorumluluğu olmadığından ona ceza verilmez. ${ }^{11}$ Mağdura ceza sorumluluğunun olmayışı Hz. Peygamberin "Ümmetimden hata, unutma ve ikrah (zorlama) durumlanndaki filleri affedilmiştir."12 hadisine dayandırılmaktadır.

\section{Hetk-i Irz (Tecavüz) Suçunun Hukûkî Niteliği}

Günümüz hukuk normlarına göre cinsel bir amaçla veya cinsel arzuları tatmin amacıyla gerçekleştirilen hareketlerin tamamı birer cinsel davranıştır. Kişilere karşı bu cinsel davranışların gerçekleştirilmesi, cinsel dokunulmazlığın ihlalini doğurur. Cinsel suçlar genel olarak cinsel saldırı ve cinsel taciz şeklinde iki kategoride ele alınır. Cinsel saldırı suçları mağdurun vücut dokunulmazlı̆̆ını ihlal suretiyle işlenir. Cinsel taciz suçları ise vücut dokunulmazlığını ihlal etmeksizin işlenebilir niteliğe haizdir. ${ }^{13}$ Cinsel dokunulmazlığa karşı suçlar Türk Ceza Kanunu'nda, cinsel saldırı (m.102), çocukların cinsel istismarı (m.103), reşit olmayanlarla cinsel ilişki (m.104) ve cinsel taciz (m.105) başlıkları altında toplanarak cezai müeyyideye bağlanmıştır.

11 Ebu Muhammed Abdullah İbn Kudâme, el-Muğni Şerb-u Mubtasaru'l-Harakî̀ (Riyad; Dâr-u Âlemi'l-Kütüb, 1997), 12: 347; İbn Muhammed İbn Habib el-Mâverdî, elHâvi'l-Kebîr fî Şerh-i Mubtasaru'l-Müzenî (Beyrut: Dâru'l-Kütübi'l-İlmiyye, 1994), 13 :

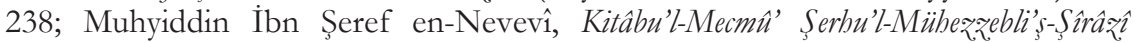
(Cidde: Mektebetü'l-İrşâd, ts.), 22: 49.

12 İbn Mâce, "Talâk", 16".

13 Mehmet Reşat Koparan, “5237 sy. TCK’da Cinsel Saldırı ve Cinsel Taciz Suçları”, Kayseri, 2009. (erişim: 17 Temmuz 2018, http://www.cezabb.adalet.gov.tr/makale/197.pdf) 
Hetk-i 1rz (Tecavüz) suçu, nitelikli cinsel saldırı (m.102) suçu kapsamında değerlendirilmekte ve vücuda organ veya sair cisim sokarak işlenmesi durumunda söz konusu olmaktadır. Erkek veya kadın herkes bu suçun hem faili hem de mağduru olabilmektedir. Mağdurun vücuduna vajinal, anal veya oral yoldan organ veya cisim sokulması suçun maddi unsurunu oluşturmaktadır. Suçun manevi unsuru ise nitelikli cinsel saldırının kasten ya da kasta benzer bir şekilde işlenmesidir. Failin intikam, kıskançlık veya benzeri bir saikle hareket etmesi halinde de suçun manevi unsuru gerçekleşmiş olur. Hetk-i 1rz suçunun mağdurun bilgi ve iradesi dışında gerçekleşmesi suçun hukuka aykırılık unsurunu oluşturur. $^{14}$

\section{1. İSLAM HUKUKUNDA HETK-İ IRZ (TECAVÜZ) SUÇUNUNU HUKUKİ DAYANAĞI}

\subsection{Hetk-i Irz (Tecavüz) Suçuyla İlgili Hadis Rivayetleri}

Hetk-i 1rz suçuyla ilgili hadis kaynaklarında değişik rivayetler mevcuttur. Tirmizî (ö. 279/892) konuyla ilgili hadisleri "æinaya zorlanan kadin" başlı̆̆1 altında verirken, Ebu Dâvud (ö. 275/888) ilgili hadisi "Haddi (gerektiren bir suc) işleyenin gelip ikerar etmesi" başliğ1 altında ele almaktadir.

Tirmîzî'de geçen konuyla ilgili ilk hadiste, Vâil b. Hucr'un babasindan rivâyetine göre, şöyle demiştir: Rasûlullah (s) döneminde bir kadın (hetk-i 1rza) zorlanmıştı. Rasûlullah cezayı (haddi) kadından kaldırdı, zorla bu işi yapan kimseye tatbik etti. Rasûlullah (s) kadın için verilmesi gereken bir mehir zikretmemiştir. ${ }^{17}$ Bu rivayet ayn şekilde İbn Mâce'de (ö. 273/ 887) de yer almaktadır. ${ }^{18}$

Tuhfetu'l-Ahvezî'de, bu hadisin "garip hadis" isnadında inkıta olduğu ifade edilmektedir. Buharînin (ö. 256/869)

\footnotetext{
14 Mehmet Reşat Koparan, 5237 sy. TCK’da Cinsel Saldrn ve Cinsel Taciz Suçar, 7.

15 Tirmizî, "Hudûd", 22.

16 Ebû Dâvûd, "Hudûd", 8.

17 Tirmîzî, "Hudûd", 22.

18 İbn Mâce, "Hudûd", 30.

19 Garîb: Hadisi, sıka ravilerden, zaîf ravilerle birlikte sadece bir sıka ravinin rivayet etmesi, herkes ayn şekilde rivayet ederken bir ravinin biraz farklı rivayet etmesi
} 
naklettiğine göre râvî, Vâil b. Hucr babasından hadis işitmemiştir; çünkü râvinin babası vefat ettikten birkaç ay sonra dünyaya geldiğine veya onun, babasının ölümünden önce dünyaya geldiğine dair rivayetler bulunmaktadır. ${ }^{20}$

Tirmizî, râvinin kadına Rasûlullah'ın mehir takdir edip etmediğine dair bir beyanda bulunmadığına dikkat çekiyor. Yoruma göre bunun sebebi, Rasûlullahın bu gibi durumlarda kadının mâruz kaldığ1 tecavüzü maddî olarak telâfi eden bir meblağ takdir etmiş olmasıdır. Bundan dolayı Tirmizî bu eksikliğe dikkat çekmiştir. ${ }^{21}$

Tirmîzî̀de geçen ikinci hadiste Alkame b. Vâil el Kindî̀nin babasından rivâyetine göre: Rasûlullah (s) zamanında mescitte cemaatle namaz kılmak için evinden dışarı çıkan bir kadını bir adam yakaladı ve üzerine kapanarak ona tecavüz etti. Kadın bağırınca adam kaçtı. O esnada oradan başka bir adam geçiyordu. Kadın dedi ki: Bana tecavüz eden adam budur. Muhâcirlerden bir grup oradan geçiyordu. Yine kadın o adam bana tecavüz etti dedi. Kadının kendisine tecavüz ettiğini sandığ1 kimseyi yakalayıp kadına getirdiler. Kadın: "Evet işte budur" dedi. Bunun üzerine adamı Rasûlullah (s)'e getirdiler. Recmedilmesini emredince, kadına gerçekten tecavüz eden kişi ayağa kalkarak: "Ey Allah'ın Rasûlü bu cezanın uygulanacağı kimse benim" dedi. Peygamber (s), kadına "sen git Allah seni affetsin" dedi. Suçsuz yere yakalanan adama da gönül alıcı sözler söyledi. Gerçek suçlu adama ise: "Onu recmedin" buyurdu ve şöyle devam etti. "Bu adam öyle bir tövbe etti ki, böyle bir tövbeyi Medine ahalisi yapsaydı tövbeleri kabul edilirdi." 22

Şârihler bu rivayetlerle ilgili bir müşkile dikkat çekmektedir. Rasûlullah, birinci şahsin recmedilmesine, ikrar veya beyyine olmadan hükmetmiştir ki, bu durum muhâkeme usulüne aykırıdır. Recm için ya itiraf veya dört erkek şâhidin şehâdeti şart olmasına karşın söz konusu

gibi, bir yönden özellik, farklılık arz eden hadis. Bkz. Abdullah Aydınlı, Hadis Istılâblar Sö̊lüğ̈̈ (İstanbul: İFAV, 2011). 85.

20 Ebu'l Ula Muhammed Abdurrahman b. Abdurrahim el-Mübarekfurî, Tubfetu'lAbvezị̂ bi Şerbi Câmii't-Tirmî̌r (b.y.: Dâru'l-Fikr, ts.), 5: 16.

21 Mübarekfuri, Șerbi Câmiì't-Tirmîẑ̂, 5: 16.

22 Tirmîzî, "Hudûd", 22; Ebu Dâvud, "Hudûd", 8. 
olayda bunlar mevcut değildir. Bu durumda kadının kazf cezasına mahkum olması gerekeceği ifade edilmektedir. Bu olayla ilgili belki de zanlının getirildiği, mesele daha tahkik safhasında iken gerçek suçlunun itirafta bulunduğu, râvînin olayı zamanla unutup biraz değiştirerek bu şekilde anlatmış olabileceği şeklinde bir yorum yapılmaktadır. ${ }^{23}$

İbnu'l-'Arabî (ö. 543/1148) Tirmizî'deki, Hz. Peygamber'in birinci adamı recm için götürülmesini emretmesi hakkında; "Bunda büyük bir hikmet vardır. Hz. Peygamber, bu adamın recm edilmesini istedi, ta ki asıl bu işi yapan kendiliğinden ortaya çıssın; çünkü olay henüz araştırma safhasındadır ki bu, hukukun ortaya çıkması için iyi bir metottur. Ancak böyle bir metod, sadece Peygamberler için câizdir. Diğer insanlar için caiz olamaz. Çünkü onlar sadece zâhiri bilebilirler, Peygamberlere ise Allah, işin iç yüzünü bildirir." ${ }^{24}$ şeklinde bir yorum yapmaktadir.

\subsection{Mezheplerde Hetk-1 Irz (Tecavüz) Suçunun Cezas1}

\subsubsection{Hanefî Mezhebi}

Zor kullanarak bir kadınla zina eden kişiye Hanefillere göre, had cezas1 gerekir; ancak mehir tayini gerekmez. ${ }^{25}$ Kadının rızası olmamas1 sebebiyle burada kadına had cezası yoktur. ${ }^{26}$ Hanefiller erkeğin kadını zorlayarak işlediği hetki-1 1rz suçunu, rızasıyla işlediği zina suçundan daha ağır bir suç kabul etmekle birlikte, her iki suç için de zina haddi cezasını uygun görürler. Bu konuda zina haddi ile mehri birleştirmemeyi, hırsızlık suçundaki el kesmeye ve çalınan malın iadesinin gerekmemesine benzeterek bu hükmü verirler. Ayrıca Ebu Hanife, "Hz. Peygamber (s) el-beğiyye'ye (zina eden kadın'a) mehir vermeyi yasakladı"27 şeklindeki rivayeti delil alarak faile mehir gerekmeyeceğini söylemiştir. Ebu

23 İbrahim Canan, Kütüb-i Sitte Tercüme ve Şerbi (İstanbul: Akçağ Yayınları, 1995.), 6: 221-222.

24 İbnu'l-Arâbî, Ebû Bekr Muhammed b. Abdullah, Ârzatu'l-abvezî̉bi șerbi Sabih etTirmiẑ̨̀ (Beyrut: Daru'l-Kütübi'l-İlmiyye, 1995), 6: 237-238.

25 Mâverdî, el-Hâvi'l-Kebîr, 12: 296; Serahsî, el-Mebsud, 9: 53; 12: 240; Kâsânî, Bedâiu'sSanâî, 12: 319; İbn Kudâme, el-Muğnî, 12: 172.

26 Kâsânî, Bedâiu's-Sanâî, 7: 319.

27 Buhârî, "Talak", 49. 
Hanife'ye göre faile şüphenin yokluğu ile had gerekirken, şüphenin varllğ1 ile mehir gerekir. Had ve mehirin ikisi bir arada ceza olarak bulunmaz. ${ }^{28}$

Hanefilere göre, failin hetk-i 1rz suçu netice itibariyle noksansız bir zina fiilidir. Zina suçunun gereği ise had cezasıdır. İctihad yoluyla bu hükme ekleme yapılarak faile ayrıca bir de tazminat öngörülmez. Diğer taraftan Hanefîler, erkeğin kız çocuğu ile veya akıl hastası ya da uyuyan bir kadınla (zorla) zina etmesinde de aynı cezayı öngörürler. Akıl hastası bir erkeğin, aklı yerinde bir kadına karşı hetk-i 1rz suçu işlemesi durumunda her ikisi içinde herhangi bir ceza öngörülmemiştir. ${ }^{29}$

Küçük kız çocuklarına karşı işlenen hetk-i 1rz suçunun cezas1, Hanefî mezhebinde ta'zir cezasıdır. Böylesi bir suç işleyen faile had cezası öngörülmez. Had cezası verilmemesi iki gerekçeye dayandır1lır: Birincisi; zina haddinin gerekmesi, zina eyleminin bütün unsurlarının oluşmasına bağlıdır. Eylemin unsurlarının oluşması ise zina konusunun eksiksiz olması ile gerçekleşir. Küçük kız çocuklarına karşı işlenen hetk-i 1rz suçunda eylemin unsurları tamamlanmış olmaz. Bu nedenle böylesi bir durumda faile had cezası uygulanmaz. İkincisi; had cezaları caydırmak amacıyla konulur. Caydırmak ise ancak insan doğasının ilgi duyduğu şeylerde söz konusu olabilir. Hâlbuki aklı başında hiç kimsenin doğası, cinsel istek duymayan ve cinsel ilişkiye dayanamayan küçük bir kızla cinsel ilişkiye girmeye yanaşmaz. İşte bu nedenle böyle bir durumda faile had cezas1 verilmez. Ancak bu kimsenin cezas1 ta'zir cezası olarak verilir. $^{30}$

Hetk-i 1rz suçunda erkeğin kadına zor kullanması, kadın açısından, işlenen suçun günahını ve cezasını ortadan kaldırıcı bir vasıf olarak görülmüştür. Hatta kadının ölüm veya yaralama tehdidi ile cinsel ilişkiye zorlandığında erkeğe direnmeyebileceğine dair ruhsat da verilmektedir. ${ }^{31}$

Maddi darbe veya tecavüzün, idrar ve cinsî temas yolunu yırtıp tek yol haline getirmesi veya uzvun etrafındaki başka yırtıkların oluşması

\footnotetext{
Mâverdî, el-Hâvi'l-Kebîr, 12: 240; Kâsânî, Bedâiu's-Sanâî, 7: 319.

Serahsî, el-Mebsud, 9: 53-54; 24: 90.

Serahsî, el-Mebsud, 9: 75.

31 Serahsî, el-Mebsud, 9: 54.
} 
klasik fikıh kitaplarında ifdâ (الافضاء) kavramıyla ifade edilir. ${ }^{32}$ Hanefiler hetk-i ırz suçunda kadına verilecek diyeti (tazminatı), kadının organına verilen zararın ağırlığına göre tayin ederler. Bu konuda tazminin miktarı, kadının idrarının tutup tutamamasına göre, tam diyetin üçte biri veya diyetin tamamı şeklinde belirlenir. Müessir fiil neticesinde kadın idrarını tutamayacak şekilde zarar görmüşse kadına tam diyet ödenir. ${ }^{33} \mathrm{Bu}$ diyete

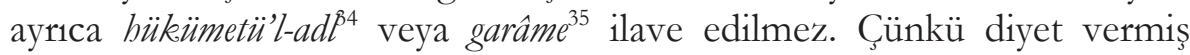
olmakla hükümet-i adl ve garâme diyetin içinde verilmiş kabul edilir. Örneğin, dilin kesilmesiyle konuşma yeteneğinin kaybolmasında sadece dilin diyetinin verilmesiyle yetinilmesi veya gözün çıkartılmasıyla sadece gözün diyetinin verilmesi, görme yeteneğinin kaybolmasının göz diyetinin içine dahil edilmesinde olduğu gibi ifdâ sebebiyle verilen diyete uzvun kabiliyetini kaybetmesinin tazmini dahil edilmiş sayllır. ${ }^{36}$ İmam Ebû Hanîfe (ö. 150/767) ve İmam Ebû Yusufa (ö. 182/798) göre ifdâ meydana gelmekle beraber boşaltım sisteminin herhangi bir zaafa uğramaması durumunda ödenecek diyet miktarı tam diyetin üçte biri şeklindedir. ${ }^{37}$

Diyetin bu şekilde tespit edilmesi, hetk-i 1rz suçundaki maddi yaralanma olan ifdâ ile vücudun iç bölgelerindeki yaralanmalar olan caife arasında benzerlik ilişkisi kurularak, caifeye öngörülen 1/3'lük diyetin, ifdâ için de esas alındığı görülmektedir. ${ }^{38}$ Hanefîler faile yükletilen $1 / 3$ veya tam diyeti, hetk-i 1rz suçunun karşılığ1 olarak değil, vücuttaki bir organın kısmen veya tamamen işlevsiz hale gelmesine binaen tespit

32 Muhammed Alîş, Şer'u Menh, 4: 414; Abdu'l-Mun'im, el-Musdalehât, 1: 251; Vizâratü'l-Evkâf ve'ş-Şuûni'l-İslâmiyye, el-Mevsuatui'l-Fıkhiyye, Kuveyt: 1983, 21: 68.

33 Kâsânî, Bedâiu's-Sanâî, 7: 319.

34 Hükümetü’l-Adl: Gayr-i mukadder erş, tazminat olup, miktarı şer'an belirlenmiş olmayan, bilirkişilerce usulü dairesince takdir ve tayin edilecek olan diyettir.

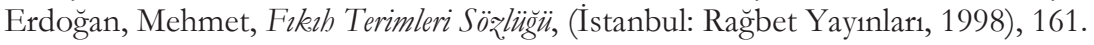

35 Garâme: Tazminat, diyet gibi edası lazım olan şey ve böyle bir şeyi eda etmek.

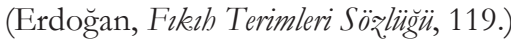

36 Mâverdî, el-Hâvi'l-Kebîr, 12: 294.

37 Ebû Yusuf Yakup b. İbrahim, Kitâbu'l-Harâc (Beyrut: Dâru'l-Ma'rife, 1979), 158; Muhammed ibn Hasan eş-Şeybânî, Kitâbu'l-Asl (el-Ma'rûfbi'l-Mebsûd) (Beyrut, Âlimu'l-Kütüb, 1990), 4: 466.

38 Mâverdî, el-Hâvi'l-Kebîr, 12: 294; Dağc1, Müessir Fïller, 213. 
etmektedirler. Bu durumda yukarıda geçtiği üzere had cezası ile mehir yükümlülüğünü birleştirmeme prensipleri geçerliliğini korumaktadır. Zira diyet verme durumunda kadına ödenen meblağ, mehir değil, işlevsiz kılınan organın karşılığıdır. ${ }^{39}$

Hanefî mezhebine göre 1rza geçme suçu itiyat haline getirilmişse fail siyaseten katl cezası ile cezalandırılır." ${ }^{\text {"40 }}$ Irza geçme sebebiyle mağdur ölürse, faile hem had hem de mağdurun diyetinin ödetilmesi cezası verilir. ${ }^{41}$

\subsection{2. Şâfîî Mezhebi}

İmam Şâfî̀’ye (ö. 204/819) göre, zor kullanarak bir kadınla zina eden kişiye, had cezası gerektiği gibi kadına mehr-i misil ödenmesi de gerekir. ${ }^{42}$ Şâfî̂lere göre zinaya zorlanan kadına mehr-i mislin yanında ayrıca bir de diyet-i ifdâ gerekir. Bir üçüncü yaptırım olarak bekâret erş̧ $\iota^{43}$ gerekip gerekmeyeceği hususunda mezhep içinde iki görüş vardır. Birincisine göre zinaya zorlanan kadına bekâret erşi gerekli görülmezken, ikincisine göre gerekli görülmüştür. ${ }^{44}$

Diğer taraftan zinaya zorlanan kadina herhangi bir ceza öngörülmez. Kadına had cezasının gerekmemesine; "Ümmetimden hata, unutma ve ikrah (zorlama) durumlarındaki fiilleri affedilmiştir." 45 hadisi delil getirilmektedir. ${ }^{46}$

Şâfiîler faile verilecek had cezası yanında, kadına mehir verilmesi gerektiğine dair Hz. Peygamberin "Herhangi bir kadın velisinin izni olmadan nikâhlanırsa, o kadının nikâhı geçersizdir. Şayet erkek kadına dokunursa (ondan yararlanırsa) kadına mehir vermek gerekir ki, bu mehir

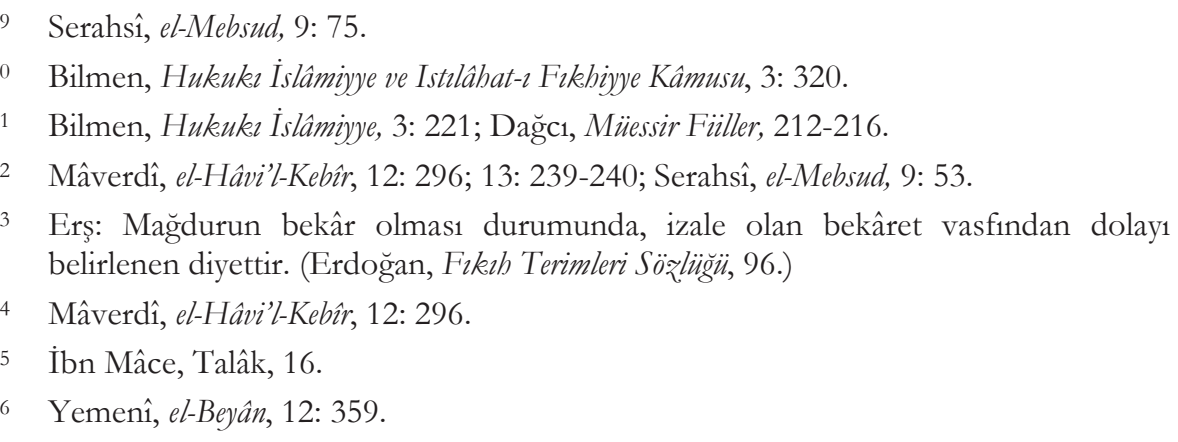


kadından yararlanmasına karşılıktır." ${ }^{47}$ hadisini delil getirmektedirler. ${ }^{48}$ Şafiîler bu hususta ikinci bir delil olarak "Hz. Peygamber (s) el-beğiyye'ye mehir vermeyi yasakladı" 49 rivayetini kullanırlar. Rivayette geçen "elbeğiyye" "ez-Zâniyetu/zina eden kadın" şeklinde açıklanmakta, hetk-i 1rz suçunun mağduru kadına "zâniye" denilemeyeceği için ona mehir vermenin zorunlu olacağ $\mathrm{kabul}$ edilmektedir. ${ }^{50}$

Şâfiî mezhebi ifdâ konusunda Hanefîlere göre ilave yaptırımlar öngörmüştür. Buna göre, ifdâ cima ile oluşabileceği gibi cima olmaksızın da oluşabilir. Cima olmaksızın oluşan ifdâ durumunda yara iyileşen yara olabileceği gibi iyileşmeyen (uzvun eski haline dönmeye imkânı olmayan) yara da olabilir. İyileşen yara ise faile hükümet-i adl gerekirken, iyileşmeyen yara durumunda faile diyet gerekir. Bu ifdâ ile birlikte bevli tutamama vasfı da birleşirse faile diyet ile birlikte hükümet-i adl gerekir. Ifda ile bekâretin izalesi birleşirse faile ifdâ diyeti ile birlikte bekâret erşi de gerekir. ${ }^{51}$

İmam Şâfî̀ kadının hetk-1 1rza karşı koymasa bile bekâret tazmini gerektiğini söyler. Bu suçla birlikte faile, kadına bir zarar verdiğinden dolay1 zarar tazmini gerekir. ${ }^{52}$

Hanefilerin aksine ${ }^{53}$ Şâfîilere göre, hetk-i ırz suçundaki maddi yaralanma olan ifdâ ile vücudun iç bölgelerindeki yaralanmalar olan caife arasında benzerlik ilişkisi kurularak, caife'ye öngörülen 1/3'lük diyetin, ifdâ için de esas alınması arasında kurulan kıyas doğru değildir. Çünkü caifedeki diyetin 1/3 olmasının sebebi bu tür yaraların iyileşme imkânının var olmasıdır. Şayet caifedeki yara iyileşmezse 1/3'lük diyet tam diyete dönüşür. Ifda da ise durum böyle değildir. Çünkü ifdâ durumunda yara

\footnotetext{
Ebâ Dâvud, "Nikâh”, 20; Tirmizî, "Nikâh”, 14; İbn Mâce, "Nikâh”, 15.

Mâverdî, el-Hâvi'l-Kebîr, 12: 294.

Buhârî, "Talak", 49.

50 Sâlim Yemenî, el-Beyân, 12: 360; Nevevî, Kitâbu'l-Mecmû', 12: 54.

51 Mâverdî, el-Hâvi'l-Kebîr, 12: 294.

52 İbn Kudame, el-Muğnî, 12: 171.

53 Mâverdî, el-Hâvi'l-Kebîr, 12: 294; Dağc1, Müessir Fïller, 213.
} 
iyileşse bile uzuv asli yapısına kavuşamayacaktır. Dolayısıyla 1/3 değil tam uzuv diyeti gerekir. ${ }^{54}$

\subsubsection{Mâlikî Mezhebi}

Malikî mezhebine göre, zinaya zorlanan kadın veya erkeğe had cezası uygulanmaz. Mâlikîler de diğer mezheplerde olduğu gibi bu konuda Hz. Peygamberin "Şüphesiz Allah Teala, ümmetimden hata, unutma ve ikrah (zorlanma) ile işlenen fiilleri bağışlamıştır" ${ }^{\prime \prime 5}$ mealindeki hadislerini delil almaktadir. Bu hadise ilaveten, zor durumda birakilarak cinsel istismara uğramış kadınla ilgili Ömer (r)'ın Ali (r)'a yönelttiği soru ve onun verdiği "O kadın zorda bırakılmıştır" cevabı akabinde Ömer (r)'in kadına bir şeyler vererek onu serbest birakması hadisesine kaynaklarda yer verilmektedir. ${ }^{56}$

Mâlikîlerden Abdurrahman b. Kasım el-Utakîye (ö.191/806) göre müessir fiil neticesinde kadın idrarını tutamayacak şekilde zarar görmüşse kadına tam diyet ödenir. İmam Mâlik (ö. 179/795) bu durumda kadına tam diyet değil, hükümetü’l-adl ödenmesi gerekeceği görüşündedir. ${ }^{57}$

\subsubsection{Hanbelî Mezhebi}

Hanbelî mezhebinde hetk-i ırza maruz kalan kadının, idrarını tutamayacak derecede zarar görmesi durumunda faile hem tam diyet hem de mehr-i misil gerekir. ${ }^{58}$ İdrarını tutabilecek derecede zarar görmesi durumunda ise $1 / 3$ diyet gerekli olacağ1 kanaati hâkimdir. ${ }^{59}$ Çünkü fail, hakkı olmayan bir birliktelikte bulunmuştur ki onun bu konuda hukuki

\footnotetext{
54 Mâverdî, el-Hâvi'l-Kebîr, 12: 294.

55 İbn Mâce, "Talâk", 16.

56 Abdurrahmân el-Garyânî, el-Fıkhu'l-Mâlikî̀ ve Edilletuhu, (Beyrut: Müessesetu'rReyyân, 2002), 4: 627.

57 “Diyet", el-Mevsûatü'l-Fıkhıyye, (Kuveyt: Vuzâratu'l-Evkâf ve'ş-Şuûni'l-İslâmiyye, 1992), 21: 68.

58 İbn Kudame, el-Muğnî, 21: 172.

59 “Diyet”, el-Mevsûatü'-Fıkhıyye, 21: 68.
} 
izni yoktur. Diğer suçlarda olduğu gibi faile telef ettiği şeyin tazminatı yükletilir. ${ }^{00}$

Failin, mehr-i misille birlikte bekâret erşi ödemesi de gerekip gerekmeyeceği konusunda farklı iki görüş vardır. Bunlardan birincisi, sadece mehr-i misli gerekli görüp bekâret erşinin verilmemesi gerekeceğini savunur. Şüphesiz, bekarın mehri dul kadının mehrinden daha çoktur. Bunların ikisi arasındaki fark, bekâret erşini kapatır. Yani bekâret erşine gerek kalmayıp mehr-i bekâre (mehr-i misil) ile bu fark önceden verilmiş olur. Eşinde sahip olduğu haktaki gibi bekâretin izalesine tazmin gerekmez. İkincisi ise bekâret erşinin verilmesinin gerekli olduğunu söyleyenlerin görüşüdür. Bunlara göre buradaki bekâret, düşmanlıkla fail tarafindan zayi edilen bir mahaldir. Nitekim parmakla bekâretin bozulması durumunda tazmin gerektiği gibi failin bekâreti zorla izale etmesi de erşi gerektirir. ${ }^{61}$

Hanbelî fakihlere göre, kadının hetk-i ırza karşı koymaması durumunda bekâret tazmini gerekmez. Çünkü kadının uğradığı zarar, onun faile karşı koymaması neticesinde oluşmuştur. Yani fiil kadının rızası ile gerçekleşmiştir. Fiilin kadının rızası sonucu oluşması durumunda fail mehr-i misli ve bekâret erşini ödemez. ${ }^{62}$

Sünnî ekole mensup mezheplerin hetk-i 1rz/tecavüz suçu işleyen fail için öngördükleri cezaî müeyyideleri tablo halinde şu şekilde özetleyebiliriz:

\footnotetext{
İbn Kudame, el-Muğnî, 12: 171.

İbn Kudame, el-Muğnî, 12: 171.

İbn Kudame, el-Muğnî, 12: 171.
} 


\begin{tabular}{|c|c|c|c|c|}
\hline \multicolumn{5}{|c|}{ HETK-I IRZ (TECAVÜZ) SUÇUNUN CEZASI } \\
\hline MEZHEP & HANEFÎ & ŞAFİî & MÂLİK̂́ & HANBELÎ \\
\hline Hafif İfzâ & $\begin{array}{l}\text {-Had cezasi } \\
\text { verilir. } \\
-1 / 3 \quad \text { diyete } \\
\text { hükmedilir. } \\
\text {-Mehre } \\
\text { hükmedilmez. }\end{array}$ & $\begin{array}{l}\text {-Had cezasi } \\
\text { verilir. } \\
\text {-Mehir-i misle } \\
\text { hükmedilir. }\end{array}$ & & $\begin{array}{l}\text {-Had cezas1 } \\
\text { verilir. } \\
\text {-Mehir-i misle } \\
\text { hükmedilir. } \\
-1 / 3 \text { diyete } \\
\text { hükmedilir. }\end{array}$ \\
\hline Ağır İfzâ & $\begin{array}{l}\text {-Had cezası } \\
\text { verilir. } \\
\text {-Tam diyete } \\
\text { hükmedilir. } \\
\text {-Mehre } \\
\text { hükmedilmez. } \\
\text {-İmam } \\
\text { Muhammed'e } \\
\text { göre tam diyet } \\
\text { ve mehr-i misil } \\
\text { gerekir. }\end{array}$ & $\begin{array}{l}\text {-Had cezası } \\
\text { verilir. } \\
\text {-Mehir-i misil } \\
\text { gerekir. } \\
\text {-Tam diyet } \\
\text { gerekir. } \\
\text {-Hükümet-i } \\
\text { adl gerekir } \\
\text {-Bekaret erşi } \\
\text { gerekir. }\end{array}$ & $\begin{array}{l}\text {-Had cezası } \\
\text { verilir. } \\
\text {-Bazı } \\
\text { Malikîlere } \\
\text { göre tam } \\
\text { diyete } \\
\text { hükmedilir. } \\
\text {-İmam göre } \\
\text { Malik'e } \\
\text { Hükümet-i } \\
\text { adle } \\
\text { hükmedilir. }\end{array}$ & $\begin{array}{l}\text {-Had cezasi } \\
\text { verilir. } \\
\text {-Mehir-i misil } \\
\text { gerekir. } \\
\text {-Tam diyet } \\
\text { gerekir. }\end{array}$ \\
\hline $\begin{array}{l}\text { Çocuklar } \\
\text { a yönelik } \\
\text { hetk-i 1rz }\end{array}$ & $\begin{array}{l}\text {-Had cezasi } \\
\text { verilmez. } \\
\text {-Ta'zir cezas } \\
\text { verilir. } \\
\text { - } 1 / 3 \text { veya tam } \\
\text { diyete } \\
\text { hükmedilir. }\end{array}$ & & & \\
\hline $\begin{array}{l}\text { Alışkanlı } \\
\text { k (İtiyat) } \\
\text { haline } \\
\text { gelmiş } \\
\text { hetk-i 1rz }\end{array}$ & $\begin{array}{l}\text {-Siyaseten katl } \\
\text { cezas1 verilir. }\end{array}$ & & & \\
\hline
\end{tabular}




\subsection{5. Şia Mezhebinde Hetk-i Irz}

Şia mezhebinde tecavüz suçuyla ilgili hükümlerde müracaat edilen iki hadis rivayeti vardır. Bunlarda ilki 5041 numaralı hadiste, Zürâre'den gelen rivayetlerin birinde, "Müslüman bir kadına zorla sahip olan erkek hakkında 'öldürülür' denilmektedir.” İbn Mahbûb’un rivayet ettiği 5042 numaralı ikinci hadiste nakledildiğine göre, "Bir kadına zorla sahip olan adam hakkında: muhsan olsun veya olmasın 'öldürülür' denilmektedir." "'3

Şia fikıh kaynağında tecavüz suçunun cezası şu şekilde tespit edilmektedir:

"Bir kişi, kadını zinaya zorlarsa o kişiye had gerekir. Çünkü o zânidir. Fakat kadına had gerekmez. Adama, kadına vermek üzere mehir yükletilir. Kadın ister özgür olsun ister köle olsun fark etmez. Bununla birlikte kadın özgür ise alacağı mehir kadının kendisine verilirken, kadın özgür değilse mehir kadının sahibine verilir. Kadından had düştüğü için kadına mehir verilmesi gerekmektedir." ${ }^{94}$

Rivayetlerden de anlaşılacağı üzere Şia mezhebinde tecavüz suçu için ölüm cezası öngörülmüştür. Failin bekâr veya evli olması sonucu değiştirmemektedir. Diğer taraftan suça maruz kalan mağdura mehir ödenmesi gerekir. Kadınının özgür olması durumunda mehir kadının kendisine verilirken, köle olması durumunda mehir kadına değil, sahibine verilir.

Buraya kadar hetk-i 1rz suçunun İslam hukuk mezheplerinde ne şekilde ele alındığı incelendi. Osmanlı kanunnamelerinin şer'î hukuku referans alması sebebiyle bundan sonraki bölümde hetk-i 1rz suçuna Osmanlı Kanunnamelerinde ne tür cezâî yaptrrımlar öngörüldüğü incelenecektir.

63 Celîlebî Ca'fer Muhammed bin Ali İbn Bâbeviyye, Men lâ Yabzurbu el-Fakîhu (Lübnan, Müessesetü'l-A'lemî, ts.), 4: 35.

64 Ca'fer Muhammed bin Huseyn İbn Ali et-Tûsî, el-Mebsûd fî Fikbi'l-İmâmiyye, (Beyrut: Müessese el-Garî, ts.), 3: 73. 


\subsection{Osmanlı Kanunnamelerinde Hetk-i Irz ve Cezası}

Osmanlı devleti hukuk sisteminde İslam hukukunun (șer’i hukuk) yanı sıra ${ }^{65}$ padişahların fermanlarıyla zaman ve zemine göre değişebilen örfî hukuk adında ayrı bir hukuki düzenleme bulunmaktadır. İslam ceza hukukunda cezalar had, kisas ve ta'zir şeklinde üçlü bir taksime tabi tutulmuş, bunlardan ta'zir cezasının tespiti ulu'l-emre (yetkili makama) bırakılmıştır. Osmanlı ceza hukukunda esas hükümler şer'î hükümler olmakla birlikte ta'zir cezaları alanında ulu'l-emre verilen yetkiden dolayı kanunnamelere ceza hükümleri de konulmuştur. Oluşturulan bu hukuk sistemi örfi hukuk olarak isimlendirilmiştir. ${ }^{66}$

Osmanlı kanunnâme ve fetvâlarında hetk-i ırz suçu ile ilgili hükümlerin kronolojik sırayla tespiti, Osmanlı hukukunun konuya hangi bağlamda yaklaşıldığını bilmek açısından önemlidir.

\subsubsection{Fatih Sultan Mehmed'in Umumî Osmanlı Kanunnâmesi}

Madde 1- Ë̆er bir kişi zina kulsa şeriat buzurunda sabit olsa ol zina kelan evlü olsa ve dabi bay olursa ki bin akçaya dabi ziyadeye gücü yeterse cerem (cereme) ügyüz akça alma evsatül-hal olursa kim altryüz akşaya malik ola ceremi

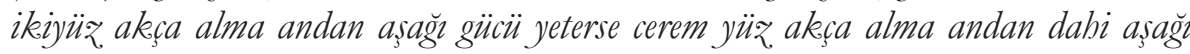
balli olursa elli akça andan aşağ̀ ki gayet fakürül-hal olursa kırk akça cerem alma.

Madde 2- Eğer zina kilan ergen olursa bin aksaya dabi ziyade gücü yeterse cerem yüz, akesa alma eğer orta halli olursa altvyür. akçaya gücü yeterse elli akça cerem alma andan aşağr dörtyüre gücü yeterse kirk akça gayet fakir olsa otuz. akęa cerem alma.

65 Mehmet Akif Aydın, "Kanunnameler ve Osmanlı Hukukunun İşleyişindeki Yeri”, Osmanlı Araştırmaları, 14, (2004): 40.

66 Ahmet Akgündüz, "Kanunnâmelerdeki Ceza Hukuku Hükümleri ve Şer’̂̂ Tahlilleri”, İslami Araştırmalar Dergisi, sayı 12/1, (1999): 1. 
Madde 7- Eğer biregünün (bir kimsenin/başkasinn) evine girse zina kasdine olursa evlü ceremin vere eğer ergen ise ergen ceremin vere ol zina eden gibi yukar tafsil üzere ki beyan olundu. ${ }^{67}$

Fatih dönemi Umumî Osmanl kanunnamesinin 7. maddesinde zina kastı ile başkanının evine giren kimseye evli veya bekâr olmasına göre miktarı değişmek kaydıyla 1. ve 2. maddede miktarları belirlendiği şekliyle para cezası öngörülmüştür. 7. maddede başkasının evine girme eyleminde "zorla" girme kaydı yoktur. Dolayısıyla bu maddenin hetk-i 1rz suçunun cezasını açıkça düzenlediğini söylemek pek mümkün değildir. Fakat kanun maddesinde geçen "Ĕger biregünün (bir kimsenin/başkasinm) evine girse zina kasdine olursa" ifadesinde geçen "biregünün (bir kimsenin/başkasinın)" ibaresinden ketk-i 1 rz suçunun kastedildiğini söylemek mümkündür.

Osmanlı kanunnamelerinde zina suçu için öngörülen celde ve para cezalarının varlığı, bu suç için fikıh kaynaklarında öngörülen cezaların dışında yeni ceza düzenlemesi yapıldığı anlamına gelmemektedir. Söz konusu yaptırımlar suçun bazı unsurlarının eksik olması sebebiyle hadd cezası verilemeyen zina suçu davalarında, suçun cezasız kalmaması için getirilmiş tedbirlerdir. ${ }^{68}$

\subsubsection{Bâyezid Devri Kanunnâmeleri}

"Kız, ve oğlan çeken kimsenin biyanet ile bir ecnebinin evine giren kimsenin avrat ve kız, çekmeğe bile varan kimsenin içmeği kesile." 69

II. Bâyezid devri kanunnamesinin bu maddesi hetk-i 1rz suçu işleyen kimseye hadım cezası uygulanmasını öngörmektedir.

67 Ahmed Akgündüz, Osmanl Kanunnâmeleri ve Hukukî Tablilleri: 1. Kitap Osmanl Hukukuna Giriş ve Fatih Devri Kanunnameleri, (b.y. Osmanlı Araştırmaları Vakfı Yayınlar1, ts.), 347-348.

68 Ekrem Buğra Ekinci, Osmanl Hukuku, (İstanbul: Ar1-Sanat Yayınları, 2014), 346.

69 Ahmed Akgündüz, Osmanh Kanunnâmeleri ve Hukukî Tablilleri: 2. Kitap Bâyezid Devri Kanunnameleri, (b.y. Osmanlı Araştırmaları Vakfı Yayınları, ts.), 42-43. 


\subsubsection{Yavuz Sultan Selim Devri Kanunnâmeleri}

"Bir kiși zina kastzyla bir kișinin evine girse evlü olursa evlü cürmin vire ve eğer ergen olursa ergen cürmün vire kerz oğlan çeken ve hyyanet ile bir kimsenin evine girenin ve kız ve avret çekmeğe bile varan kimesneye siyaset için zekeri kesile. "ᄁ0

I. Selim Kanunnamesi'nde tecavüz suçunun tanımı yapılmış ve bu suç için yaptırım tespit edilmiştir. $\mathrm{Bu}$ kanunnamenin diğer kanunnamelerden bir farkı daha vardır. Buna göre zina suçu ve tecavüz suçu birbirinden ayrılarak, bu suçların cezaları açık bir şekilde aynı kanun maddesi içinde farklı düzenlenmiştir.

Diğer taraftan maddedeki "siyaset için zekeri kesile" ifadesi hetk-i 1rz suçunun cezasında ağırlaştırıcı bir vasfin varlığını göstermekte olup, zina suçunun cezası ile hetk-i 1rz suçunun cezası arasındaki farklılık bu ifadeyle daha da belirgin hale getirilmiştir.

\subsubsection{Kanûnî Devri Kanunnameleri}

Kanunname-i Osmânî: (el-faslül evvel fiz-zina vel-livâtâ)

Madde 5- "Ve eğer oğlan çeken veya kır çeken kimesnelerin, biyânet ile evine girenin ve avret-kı̌çckemeğe bile varanun siyâset içün zekerlerin keseler."

Madde 7- "Ve eğer bir kimesne bir kişinin evretin veya kızın öpse veya yoluna varub söylese, kâdî mubkem ta'z̧ir edüb ağaç başına bir akçe cürm alma. ${ }^{71}$

Kanunname-i Osmânî’nin 5. Maddesi hetk-i 1rz suçunun cezasını tayin ederken, 7. maddede tecavüze varmayan bazı cinsel suçların cezası düzenlenmiştir.

\subsubsection{Fetvâlar}

Mes'ele: Zeyd Hindi nikâh olunmadan cebr ile tasarruf eylese șer'an Zeyd'e ne lẫım olur?

El-Cevab: Mubsane ise katl olunur. ${ }^{72}$

70 "Osmanlı Hukukunda Tecavüz Suçu”, Belkıs Konan, erişim: 4 Aralık 2014, http://dergiler.ankara.edu.tr/dergiler/19/1682/17941.pdf. (Belge sayfa numaras1, 158)

71 Ahmed Akgündüz, Osmanl Kanunnâmeleri ve Hukukî̀ Tablilleri: 4. Kitap Kânûnî Devri Kanunnameleri, (b.y. Osmanlı Araştırmaları Vakfı Yayınları, ts.), 297. 
Mes'ele: Zeyd, Hind'in evine girip, cebr ile tasarruf eylemek isteyip, Hind Zeyd'i ahar tarikle def'e kadir olmamakla, balta ile vurup mecrub eyleyip, Zeyd o cerahetten fevt olsa, Hind'e nesne lazım olur mu?

El-cevap: Gaza etmis olur. ${ }^{73}$

Benzer bir başka fetva şu şekildedir:

"Zeyd Ömer'in beker olan cariyesi Hind'i, gasben abz ve Hind'e zina idüp, bekâretini izale eylese Zeyd'e ne lazım gelir? olunur. $" 74$

El cevap: Yüz değnek vurulur ve cariyenin noksan bekâreti taz̧min

Ebussuud Efendi'nin (ö. 982/ 1574) fikha da uygun olan yukarıdaki fetvalarında evli kimsenin hetk-i ırz suçu işlemesi durumunda faile ölüm cezası verileceğine hükmedilmiştir. İkinci fetvada hetk-i 1rz suçuna teşebbüs eden failin mağdur tarafindan öldürülmesi durumunda mağdura herhangi bir ceza yaptırımı öngörülmemiş, konu nefsi müdafaa kapsamında değerlendirilmiştir. Üçüncü fetvada ise bâkire bir kıza yönelik hetk-i 1rz suçu işlenmesi durumunda faile had cezası verilmesine, ilaveten diyet ödeme yükümlülügüne hükmedilmiştir.

Osmanlı hukukunda yukarıda değindiğimiz kanunnamelerin ve fetvaların dişında bir de 1858 tarihli ceza kanunu bulunmaktadır. Osmanlı hukukunda hetk-i ırz suçu incelenirken konuyu klasik dönem ve tanzimat dönemi şeklinde iki döneme ayırmak daha doğru bir yaklaşım olacaktır. Zira 1858 tarihli Ceza Kanunname-i Humâyunu, batı hukukunun benimsenmesi sürecinde hazırlanmış bir kanun olup yukarıda ele aldığımız klasik dönem Osmanlı kanunnamelerinden ve fetvalarından farklılık arz etmektedir. Klasik dönem hukuku şer'î hukuku esas alırken, Tanzimat dönemi hukuku batı tarzı hukûkî normları referans almaktadır. Osmanlı dönemi hetk-i ırz suçu ve cezası bu çalışmanın birinci derecede

72 M. Ertuğrul Düzdağ, Şeybülislâm Ebussuîd Efendi Fetvalar Işı̆̆ında 16. Asır Türk Hayat, (b.y.: Enderun Kitabevi, 1983), 157.

73 Düzdağ, Şeybülislâm Ebussun̂d Efendi Fetvalar, 158.

74 Cahit Kayra, Osmanli'da Fetvalar ve Günlük Yaşam, (b.y.: Boyut Yayıncılık, 2008), 69. 
sınırları içerisinde yer almadığ1 için 1858 tarihli Ceza Kanunname-i Humâyunu'un ilgili maddeleri ${ }^{75}$ aşağıda gösterilmekle yetinilmiştir.

\section{HETK-İ IRZ (TECAVÜZ) SUÇUNUN CEZASININ KUR'AN CEZA ILKELERİ AÇISINDAN DEĞERLENDİRMESİ}

\subsection{Konunun İslam Hukuku İlkeleri Açısından Değerlendirilmesi}

Haddi gerektiren zina suçu temel klasik kaynaklarda şöyle tarif edilmiştir: Erkeğin zinası "İslâm ülkesinde, mükellef bir şahsin serbest iradesiyle, fiziksel açıdan cinsel ilişkiye elverişli, hayatta olan bir kadınla, evlilik şüphesi ve mülkiyet gibi bir bağ bulunmadan normal yoldan ilişkide bulunmasıdır. Kadının zinası da tarif edilen bu fiile rızasıyla imkân vermesidir." ${ }^{\prime 76}$

Tarifte yer alan "kadının bu fiile rızası ile imkân vermesi" kaydı zina suçu ile hetk-i 1rz (tecavüz) suçunu birbirinden ayıran en temel ayrımdır. Suçtaki vasıf değişikliği hem cezada hem de isimlendirmede değişikliğe gidilmesini zorunlu kılmıştır. Kadın zina fiiline kendi rızası ile

751858 tarihli ceza Kanunname-i Hümayunun "Hetk-i ırz edenlerin mücâzâtı beyanındadır" başlığı altında şu maddeler yer almaktadır:

197. madde, küçük çocuklara karşı cinsel suçlara hapis cezasını;

198. madde büyüklere karşı işlenen hetk-i ırz suçuna kürek cezasını;

199. madde, hetk-i ırz suçunun hizmet ilişkisinin sağladığı nüfuz sebebiyle veya mağdurun velileri tarafindan işlenmesi durumunda süresi ağırlaştırılmış kürek cezasini;

200. madde, hetk-i ırz suçu bakire bir kıza karşı işlenmesi durumunda faile kürek cezasina ilaveten tazmin cezasini;

201. madde, cinsel dokunulmazlığa karşı işlenen suçlarda hapis cezasını;

202. madde açıkça hetk-i 1rz suçuna cürret eden kimseye hapis ve para cezasını öngörmektedir. (Ahmet Akgündüz, "Mukayeseli İslam ve Osmanl Hukuku Külliyatı", Diyarbakır: Dicle Üniversitesi Hukuk Fakültesi Yayınları, 1986, 864-865; Musa Gümüş, "Osmanlı Devleti'nde Kanunlaştırma Hareketleri, İdeolojisi ve Kurumlar1”, Tarih Okulu, 14, 2013: 185.)

76 Kâsânî, Bedâiu's-Sanâi, 7: 33; Bilmen, Hukukı İslâmiyye ve Istılâhat-ı Fıkbiyye Kâmusu, 3: 197; Abdulkadir Ûdeh, et-Teşrî'u'l-Cinâiyyi'l-İslâmî, Beyrut: Müessesetü'r-Risâle, 1426. 2: 374. 
iştirak ederse dava zina davası olarak değerlendirilirken, kadının söz konusu fiile rızasının olmaması bu fiilin tecavüz suçu olarak isimlendirilmesini gerekli kilmaktadır.

\subsubsection{Suçtaki Değişikliğin Cezada da Değişiklik Gerektirmesi}

İslam hukukunda tecavüz fiilinin müstakil suç türü olarak değerlendirilmeyip, zina suçu kapsamında ele alındığına ve tecavüz filinin cezası olarak büyük oranda zina suçuna verilen had cezası ya da bu ceza yerine tâ'zir cezasının verildiğine temas etmiştik. İslam hukukunda tecavüz suçunu işleyen faile had, tâ'zir veya işlediği müessir fiil sebebiyle mağdurda meydana getirdiği fiziki yaralanmalara bedel olarak fazladan diyet/tazminat öngören hükümlerin hangi oran ve şartta Kur'an ceza ilkeleri açısından bir karşılı̆̆ının olduğu ayrı bir değerlendirme konusudur. Nitekim Kur'an ceza ilkelerinin gerek kendi iç dinamikleri ve gerekse etik ilkelere göre analiz edilmesi hem bu ilkelerin mantığının bilinmesi hem de bu ilkelerin pratikte nasıl uygulanacağının gösterilmesi açısından önem arz etmektedir. Bu bağlamda öncelikle İslam hukuk literatüründe tecavüz suçunun müstakil bir suç olarak değil, zina kapsamında görülüp ona göre ceza tayin edilmesi irdelenmelidir. Zira fikıhta genel kabul gördügü üzere, zina suçunda failin evli olması durumunda verilecek ceza ölüm olurken, failin bekar olması durumunda ceza celdeye dönüşmektedir. Evli zina faili için öngörülen cezanın tecavüz faili için de aynen uygulanması nispeten yeterli görülse de tecavüz failinin bekar olması durumunda öngörülen celde cezasının yeterli bir ceza olarak değerlendirilmesi hukuken ve ahlaken mümkün değildir.

Kur'an'da ceza suça göre belirlenir. ${ }^{77}$ Bir suçun maddi ve manevi unsurları değiştikçe, yeni oluşan suçun içerdiği vasıflara göre yeni bir ceza düzenlenmesi gerekir. Zina fiilinin içerdiği vasıflarla hetk-i ırz (tecavüz) suçunun içerdiği vasıflar aynı değildir. Zina fiilinde tarafların fiile karşılıklı rızaları varken, hetk-i 1rz suçunda durum böyle değildir. Hekt-i ırzda fail zor kullanarak tek taraflı rızayla bu fili gerçekleştirir. Mağdurun söz konusu fiile rızasının olmaması hetk-i ırz fiilini zina filinden ayıran en

77 Suç-ceza denkliğinin gerekliliği ile ilgili ayetler numaraları: 2/194; 4/123; 6/160; 10/27; 16/126; 22/60; 27/90; 28/84; 40/40; 42/40. 
önemli vasıftır. Şu halde mezheplerde zina fiiline öngörülen celde veya recm cezasının, hetk-i 1rz fiilinin cezası için de aynen kabul edilmesi Kur'an'ın temel ceza ilkelerinden olan suc-ceza denkliği ilkesiyle uyuşmamaktadır.

Suçun maddi veya manevi unsurlarından birindeki değişiklik, cezada değişikliği gerektirir. ${ }^{78}$ Bazı suçlar özel bir yükümlülük altında bulunan veya belirli vasıflara haiz kişiler tarafindan işlenebilir. Böyle suçlara "mahsus suçlar" veya "özgü suçlar" denilmektir. ${ }^{79}$ Modern hukukta var olan bu ilkeleri, Kur'an'da da görmek mümkündür. Suçun maddi unsurlarından olan fail değiştikçe cezanın da değişeceğine örnek olarak, kazf (iffete iftira) suçunu gösterebiliriz. Kur'an, başkasının iffetine iftira yoluyla leke süren fail için birkaç yaptırım öngörmüştür. Bunlar faile uygulanacak had cezasi, şabitliğinin kabul edilmemesi, fâsıklık vasfinn yüklenmesi, laneti hak etmesi şeklinde sıralanmaktadır. (en-Nûr 18/4, 23). İffete iftira suçunun başkalarına karşı işlenmesi durumunda gerekli yaptırımlar bunlardır. Fakat kişi aynı suçu eşine karşı işlerse bu suç "özgü suçlar" veya "mahsus suçlar" kapsamına girmekte ve ceza yukarıdakinden farklı bir şekil almaktadır. Yani suç konusu itibariyle aynı suç olmakla birlikte sadece suçun faili yabancı birisi değil makzufun eşi olduğunda ceza da ilkinden farklı hale gelmektedir. Eşe karşı işlenen iffete iftira suçunun cezas1, İslam hukuk literatüründe "mulâane" diye kavramsallaşan lanetleşmedir. (en-Nûr 18/6-9). Lanetleşme uygulamas1, suçun konusunun değişikliği değil, faildeki vasfin değişikliğine bir örnektir. Diğer bir ifadeyle kazf suçunda var olan iffete iftira etme niteliği; suç, ister üçüncü şahıslara isterse eşe karşı işlensin değişmemektedir. İlkinde suç başkalarma karşı işlenirken, ikincisinde eșe karşı işlenmektedir. ${ }^{80}$ Suç failindeki bir vasıf suça verilecek cezanın niteliğini de değiştirmektedir. İlkinde dört şahitle ispat edilemeyen iddia iftiraya dönüşmekte ve "celde + şahitliğin kabul edilmemesi” yaptırımı ile karşıllık

78 Suçun maddi unsurları: Fiil, Netice, Nedensellik Bağlantısı, Fail ve Suçun Konusu'ndan müteşekkildir. Suçun manevi unsurlarını ise, Kast, Taksir ve Saik oluşturur. Ayrıntılı bilgi için bakınız: (Artuk, Gökçen,Yenidünya, Cę̧a Hukuku Genel Hükümler, Ankara: Turhan kitabevi, 2011, 235-397.)

79 Artuk, Gökçen, Yenidünya, Cez̧a Hukuku Genel Hükümler, 296.

80 Suat Erdoğan, Kur'an Sünnet Işı̆̆nda Suc Ceza Uygunluğu (Mümâselet), (İstanbul: Süleymaniye Vakfı Yayınları, 2014), 106-107. 
görmektedir. İkincisinde iddia dört şahit yerine dört yeminle inkar edilmekte ve "celde + şahitliğin kabul edilmemesi" yaptırımı "Allah'ın laneti” şeklinde bir cezaya dönüşmektedir.

Aynı şekilde failin fiilde kastının olup olmaması, suça verilecek cezayı değiştiren unsurlardan biridir. Kur'an'da kasten cana kıymanın aslî cezası kısas (el-Bakara 2/178) iken, kastın olmadığı hatâen öldürmelerde yaptırım diyete (en-Nisâ 4/92) dönüşmektedir. Diğer bir ifadeyle katl suçunda kasit unsurunun varllğında ceza kısas iken, kastın olmadiğr durumda yaptırım diyettir.

$\mathrm{Bu}$ bağlamda tecavüz fiilinde suçlu ve mağdurun durumuna göre vasfin değişmesi, cezanın da değişmesini gerektirmektedir. Şu halde karşıllkel maanm olduğu zina fili ile tek tarafl mzamm olduğu hetk-i 1rz fiilini aynı kategoride değerlendirmek hukûken mümkün değildir.

\subsubsection{Hetk-i Irz Suçunun Had Suçu Olduğu Yönündeki İçtihatların Değerlendirilmesi}

Mezheplerin çoğunluğuna göre hetk-i 1rz suçu işleyen fail için öncelikle had cezası öngörmüşlerdir. Mezheplerin faile bu cezayı öngörmeleri söz konusu fili zina suçuna benzetmeleri sebebiyledir. Böylelikle zina suçu için öngörülen had cezası, tecavüz suçu için de öngörülmüştür.

Mezheplerin hetk-i 1rz suçunu zina suçu olarak değerlendirip cezasını da ona göre belirlemeleri sebep yönüyle de sonuç yönüyle de isabetli bir hüküm/ictihad değildir. Diğer bir ifadeyle, hetk-i 1rz suçunun zina suçuna benzetilerek had cezasının verilmiş olması isabetli bir kıyas değildir. Çünkü mağdurun söz konusu fiile rızasının olmaması, bu suçun zina suçuna benzetilmesine engeldir. Nitekim Kur'an'daki örneklerde de görüleceği üzere faildeki veya suçtaki birtakım değişiklikler cezayı değiştirmektedir. Kur'an'da kasten cana kıymanın aslî cezası kısas iken, hatâen cana kıymanın yaptırımı diyettir. Şahsın korunmuş malına karşı işlenen hırsızlık suçunun cezası kat-u yed iken, terör suçu kapsamında (hirâbe) gerçekleşen hırsızlığın cezası daha ağır bir cezadır. Yine üçüncü kişilere karşı yapılan zina iftirasının cezası kazf suçunu oluştururken, iftiranın eşe yapılması durumunda oluşan yaptırım kazf cezası değil mülâanedir. Örneklerden de anlaşılacağı üzere suç veya suçludaki bir vasfin değişmesi suçun tanımını veya cezayı değiştirmekte ve ortaya yeni bir sonuç çıkmaktadır. Şu halde zina suçundaki unsurlardan bir kısmının 
tecavüz suçunda da olması iki suça da aynı cezayı vermek için yeterli gerekçeyi sağlayamamaktadır.

\subsubsection{Diyet Cezasına Yönelik Değerlendirme}

İslam hukuk mezhepleri hetk-i 1rz filine had cezasının yanı sıra bir de diyet yükümlülügü gerekli görürler. Aslında mezhepler söz konusu diyeti hetk-i 1rz suçunun bizatihi karşılı̆̆1 olarak değil, diğer organlara yönelik müessir filllere öngörülen diyetler kapsamında değerlendirirler. Karın bölgesine yönelik müessir fiil olan "câife"ye kıyasla, hetk-i 1rz filine diyet takdir edilir. Karın bölgesindeki kesik ve yaralanmalara takdir edilen 1/3 miktarındaki diyet, hetk-1 1rz filindeki yaralanmalar için de öngörülür. Yukarıda ayrıntıları geçtiği üzere İslam hukuk mezhepleri genelde hetk-i 1rz neticesinde oluşan yaralanmanın çevre uzuvlara verdiği zararın ağırlı̆̆ına göre diyet belirlemesine giderler. Buna göre diyet miktarı tam veya $1 / 3$ oranındadır.

Bu noktada Şâfî̀ ve Hanbelî mezheplerinin farklı yaklaşımları dikkat çekmektedir. Bu mezhepler hetk-i 1rz fiili neticesinde oluşan yaralanmalara öngörülen diyete ilave bir basska yaptırım daha yüklerler. Bu yaptırım onların ifadesiyle "mehr-i misil" dir. Mehr-i misil, müessir fiil neticesinde oluşan yaralanmalardan bağımsız, sırf hetk-i 1rz fiilinde failin elde ettiği yarara karşılık öngörülmüştür. Tüm bu yaptırımların dışında bir de hetk-i 1rz fiiline maruz kalan kişi bekâretini kaybetmişse ona "bekâret erşi” ödenmesi gerektiğine dair ağırlıklı görüşler mevcuttur. Şâfiî ve Hanbelîlerin mehr-i misil görüşü sebep yönüyle olmasa da sonuç yönüyle isabetli görünmektedir. Kanaatimizce mehr-i misil failin elde ettiği yarar sebebiyle değil, mağdurun uğradığ 1 manevi kayıplar sebebiyle yükletilmelidir.

Netice olarak Hanefîler ve Mâlikîler hetk-i 1rz suçu işleyen faile had cezası ile birlikte genelde diyet yüklemekle yetinirlerken; Şâfiî ve Hanbelî mezhepleri had cezası ile birlikte mümkün olduğu kadar mâlî yaptırımlara ağırlık vermişlerdir. Onlar, mâlî tazminat gerekliliğini had cezalarından ayrı tutarak bu sonuca varmışlardır ki, kanaatimizce doğru olan da budur. Zira had cezaları Allah hakkı kapsamı içerisinde yer alırken, tazminatlar kul hakkı kapsamında yer alan yükümlülüklerdir. 
Allah hakkının icrası yani haddin tatbiki, kul hakkını düşürmemelidir. Hanefî mezhebinin eli kesilen hırsıza ayrıca çaldığı malı tazminle yükümlü tutmama yönünde içtihadr ${ }^{81}$ bulunmuş olsa da Hz. Peygamberin "Kişi aldığ1 şeyden onu geri verinceye kadar sorumludur" ${ }^{2}$ şeklindeki beyânı ve ayrıca benî Mahzûm kabilesinden Fatıma binti Esved b. Abdi'lEsed'in karıştığı bir hırsızlık olayında had cezası ile birlikte faile malın tazminini emretmesi, ${ }^{83}$ hukuk davalarında Allah hakk1 ve kul hakkının ayr1 ayr1 değerlendirilip hükme bağlanması gerektiği yönündeki kanaatimizi teyit etmektedir.

Kanaatimizce Hanefi mezhebinin hekt-i 1rz suçunda had cezası ile yetinip, had cezası ile tazminat yaptırımlarını birleştirmeme ilkeleri ${ }^{84}$ isabetli bir tercih değildir. Suçun unsurlarındaki farklılık cezaları çeşitlendirecektir. Had cezası Allah hakkı olarak konulan müeyyidedir. Şu halde sadece had cezası ile yetinmek, Allah hakkını yerine getirip, kul hakkını ihlal etmek anlamına gelmektedir. Oysaki Allah hakk1 ve kul hakk1 ayrı ayrı ödenmesi gereken yükümlülüklerdir. ${ }^{85}$ Bundan dolay1 kanaatimizce Hanefî mezhebinin yaklaşımı ve delilleri Şâfiî ve Hanbelî mezheplerine göre bu konuda zayıf kalmaktadır.

\subsection{Osmanlı Kanunnamelerine Yönelik Değerlendirme}

\subsubsection{Kanunnamelerde Hetk-i Irz Fiilinin Müstakil Suç Olarak Değerlendirilmesi}

Osmanlı kanunnâmeleri örfî hukukun yanında, ağırlıklı olarak şer'i hukuk kurallarına dayanmaktadır. Özellikle de 1858 tarihli Ceza Kanunname-i Hümâyunu'na gelinceye kadar, öncesinde ç1kartılan tüm kanunnamelerde bu özellik ağırlıklı olarak görülmektedir. 1858 tarihli

\footnotetext{
81 Serahsî, el-Mebsud, 9: 177.

82 Tirmizî, "Buyu", 39; Ebû Dâvud, "Buyû", 39; İbn Mâce, "Sadakât", 5.

83 Nesâî, "Kat'u-s Sârık", 5; Ebû Davud, "Hudûd”, 15; İbn Mâce, "Hudûd”, 28.

84 Serahsî, el-Mebsud, 9:53

85 İshak İbrahim b. Ali b. Yusuf el-Fîruzabâdî, el-Mühezzę fì Fıkhi'l-Imâmi'ş-Şâfiiyyi, (Beyrut: Dâru'l-Kütübi'l-İlmiyye, 1995), 3: 365.
} 
Ceza Kanunnamesi ise daha çok batılı anlayışa uygun formatta hazırlanmıştır. ${ }^{86}$

Daha önce de zikredildiği üzere hetk-i 1rz fiili İslam hukuk kaynaklarında müstakil bir suç türü olarak değil, zina suçu kapsamında değerlendirilmiştir. Tabi bu durumun doğal bir sonucu olarak faile öngörülen ceza zina suçunun cezasından farklı olmamıștır. Oysa suçtaki vasıfların değişmesiyle cezasın da değişmesi gerekir ki, bu konuya yukarıda değinmiştik.

Fatih dönemi Umûmî Osmanlı Kanunnamesi'nden sonra olmak üzere, hetk-i 1 rz fiili müstakil bir suç türü olarak Osmanlı kanunnamelerinde yerini almıştır. Bu yaklaşım, hetk-i ırz fiilinin zina kapsamından farklı bir suç türü olarak ele alınması gerektiği şeklindeki kanaatimizin yerindeliği açısından önemli bir noktadır. Kanunnameler zina suçu için farklı, hetk-i 1rz suçu için ayrı bir yaptırım öngörmüştür. Bu ayrım doğal olarak zina suçunda tarafların fiile rızalarının olması, hetk-i 1rz suçunda mağdurun fiile rızasının olmamasından kaynaklanmaktadır.

\subsubsection{Kanunnamelerde Hetk-i Irz Fiiline Hadım Cezası}

\section{Öngörülmesi}

İslam ceza hukuku ana eksen itibariyle kısas temeline dayanmaktadır. Cana ve bedene yönelik suçlarda bu ilkeye göre ceza belirlemesine gidilmiştir. İslam hukuk mezhepleri hetk-i 1rz fiilini zina kapsamına alıp buna göre ceza belirlediklerinde bir yönüyle bu fiili de kısas kapsamına almış olmaktadırlar. Zira İslam hukukunda zina suçu için had cezası takdir edilir. Zina suçuna verilen had cezası ise failin bekâr olmas1 durumunda celde cezas1, failin evli olmas1 durumunda da recm cezası olarak karşılık görür. Neticede hetk-i 1rz fiilinin failine bekâr ise celde cezası, evli ise recm cezası öngörülmüş olur. Fakat biz kaynaklarda hetk-i ırz fiili için bu iki ayrımın yapıldığına rastlayamadık.

İslam hukukunda durum böyleyken Osmanlı kanunnamelerinde durum farklılaşmışır. II. Bâyezid devri kanunnamesi, Yavuz Sultan Selim devri kanunnamesi ve Kânûnî devri kanunnamelerinde hetk-i 1rz filine karşılık hadım cezası öngörülmüştür. Hadım cezası, had cezası

86 Gümüş, "Osmanlı Devleti'nde Kanunlaştırma Hareketleri, İdeolojisi ve Kurumlar1”, 186. 
kapsamında değildir. Zira Kur'an ve sünnette bu suçla ilgili aç1k bir ceza düzenlemesi yoktur. Bu kanunnamelerde hetk-i 1rz suçuna hadım cezası öngörülürken, ceza düzenlemesinin hukuki mantığı kanaatimizce "kısas" ilkesine dayandırılmıştır. Genel anlamıyla kısas, failin işlediği suçun, aynısıyla kendisine tatbik edilmesidir. Hekt-i ırz suçunda bu düz yaklaşım, hukuki ve ahlaki olmayan bir sonuca kap1 aralar. Oysa "kisas" kavramı "aynısylla mukabele" anlamıyla değil de ayette ${ }^{87}$ olduğu gibi "bir şeyin iz̨ini takip etme"s8 anlamiyla alınacak olsa bu durumda, failin işlediği suçun aynisylla kendisine uygulanması anlamı değil, işlediği suçun misli cez̧a anlamı çıkabilir. Şu halde Osmanlı kanunnamelerinde, hukuka ve ahlaka aykırı olarak işlenen hetk-i 1rz suçunun karşıllğ̣, hukuka ve vicdana uygun olan hadım cezası olarak karşılık bulmuştur. Bu yaklaşımla hadım cezası, işlenen suçun kısası olmaktadır. Aynı hukuki yaklaşım Kur'an'ın iffete iftira (kazf) suçu için öngördügü cezada da görülmektedir. Genel kısas mantığıyla yaklaşıldığında başkasının iffetine iftira atan kimseye ceza olarak aynı iftiranın atılması şeklinde bir müeyyide gerekir. Fakat Kur'an, kazf örneğinde düz kısas mantı̆̆ıyla değil, "misil ceza" şeklinde bir müeyyide öngörmüştür ki; bu da failin suç işlerken gözettiği amacin dönüp kendisini bulması şeklinde tezahür eder. Diğer bir ifadeyle başkasını itibarsızlaştırmak isteyen kişinin, kendisi itibarsızlaştırılır. Kazf suçunun cezasında failin şahitliğinin kabul edilmemesinin anlamı budur. ${ }^{89}$ Kanaatimizce aynı hukuki yaklaşım Osmanlı kanunnamelerinde hetk-i 1rz suçunun cezası için de gözetilmiş olup, başkasının genital organını hukuka ve ahlaka aykırı olarak fiilen zedeleyen kimsenin kendi organı işlevsiz hale getirilmiştir.

Çocuk veya kadının tecavüze uğraması şeklinde ortaya çıkan suç, kendilerinin hiçbir hukukî ve ahlakî sorumluluğu olmamasına rağmen, üzerlerinde bir ömür boyu silinmez maddi/manevi/psikolojik izler bırakmaktadır. $\mathrm{Bu}$ yönüyle bakıldığında hetk-i 1 rz filliyle birlikte mağdurda meydana gelen bu kalıcı izlere karşılık, fail üzerinde fiziki

87 Kısasın "iz sürmek” ve "izinden gitmek" anlamı şu ayette mevcuttur: "Annesi, Musa'nın ablasina; onun izini takip et dedi.” (el-Kasas 28/11).

88 Mecduddin Muhammed b. Yakup Fîrûzâbâdi, el-Kamusu'l-Muhit, (Misır: Mektebetü Mustafa el-Bâbî Halebî, 1952), 2: 324-325.

89 Adem Yildırım, Kur'an-Sünnet Işı̆gnda Cezanın Amacı, (Doktora Tezi, İstanbul Üniversitesi, İstanbul, 2013), 260. 
olarak kalıcı bir iz bırakılması, İslam ceza hukukunun temeli olan "kısas" mantığıyla örtüşmektedir.

\subsection{Hetk-i Irza Yönelik Müeyyideler Hakkında Güncel Değerlendirme}

Kur’an ceza ilkeleri bağlamında düşündüğümüzde tecavüz suçu için faile iki tür yaptırım öngörüldüğüne tanık oluruz. Bunlardan ilki şahıs hakk1 kapsamındaki tazminatlar; ikincisi, kamu hakk1 kapsamındaki yaptırımlardır. Bu nedenle günaha neden olan suçla birlikte doğan Allah hakkı, günahkâr ile Allah arasında kalmaktadır. Fail işlediği bu suçtan dolayı tövbe ederse uhrevî cezadan kurtulabilir. Ancak fail tövbe etse bile insana karşı işlenen suçlara karşı verilecek cezâî yaptırım, kamu hukukunu ilgilendirdiğinden hiçbir şekilde affedilmez veya hukuk diliyle ifade edecek olursak düşmez. Çünkü tazminatlar kul hakkı kapsamında olduğu için hukuki açıdan tazmin edilmemeleri ancak mağdurun bağışlamasıyla mümkündür.

\subsubsection{Tazminatlar}

Tazminatlar kul hakkı kapsamında ele alınan yaptırımlardır. Mağdur tazminat alıp almama konusunda tercih sahibidir. Tazminatların belirlenmesi işlemi, içerisinde tıp, hukuk, fikıh, psikoloji gibi farklı ilmi branşların etkin olduğu, uzman kişilerden müteşekkil bir komisyon tarafindan yürütülmelidir. Tecavüz fiiline maruz kalan mağdurun niteliğine göre tazminatın cinsi ve miktan değişebilir. Dolayısıyla tecavüz suçunun işleniş biçimine ve mağdurum özel durumuna bağlı olarak takdir edilen cezanın aşağıdakilerden biri veya birkaçıyla birlikte ilişkilendirilmesi mümkündür.

2.3.1.1. Diyet: Tecavüz filinden dolay1 vücutta meydana gelebilecek olası doku yaralanmalarına karşılık olmak üzere tam diyet üzerinden tespit edilen maddi yaptırımdır. Bu miktar tam diyet veya $1 / 3$ şeklinde yaranın ağırlığına göre değişebilir.

2.3.1.2. Mehr-i Misil: Tecavüz filli neticesinde mağdurun evliliğinin zamansız bitmesi veya hiç evlenememe veya dengi olmayanla evlenme zorunda kalması ihtimaline binaen faile Mehr-i misil yükletilir. Örneğin bekâr kızın tecavüze uğraması neticesinde hak ettiği dengi biriyle evlenememesi veya dul biriyle evlenmek zorunda kalma ihtimali; evli 
kadının tecavüze uğraması durumunda kocasının onu boşaması gibi durumlara karşılık olmak üzere faile Mehr-i misil yükletilir.

2.3.1.3. Bekâret Erşi: Vücut bütünlügüne karşı işlenen cinayetlerde ödenen ve miktarı kanunda belirlenen diyete "erş" denilmektedir. ${ }^{90}$ Tecavüze uğrayan mağdurun bekar olması durumunda Bekâret erşi, doğal/fitrî bir değerin yitirilmesinin karşıllı̆g1 olarak faile yükletilmelidir.

2.3.1.4. Hükümetü'l-Adl: Vücut bütünlügüne karşı işlenen cinayetlerde ödenen ve denklik olmadığı için kısas uygulanamayan uzuv kat'1 ve yaralamalarda, kanunda belirtilmemiş ancak bilirkişilerin tayin ettiği diyete "bukûmet" veya "bukûmetüll-adl" denilmektedir. ${ }^{11}$ Tecavüz fiili neticesinde mağdurun sahip olduğu maddi menfaatleri kaybetmesi durumunda bilirkişilerce usulüne göre hükûmetü'l-adl takdir edilmelidir. Örneğin mağdurun işini, çevresini, itibarını kaybetmesinin karşıllı̆̆ olarak faile hükûmetü'l-adl yükletilmelidir.

Tüm bunlardan başka tecavüz fili neticesinde mağdurun vücudunun başka bölgelerinde farklı yaralanmalar oluşmuşsa bunlar ayrıca değerlendirilerek diyet tespiti yapilır. Fiil neticesinde veya fiile teşebbüs sonucu mağdur hayatını kaybetmişse bu durumda dâvâ artık cana yönelik saldırı kapsamında ele alınarak hükme bağlanır.

Tecavüz suçu için verilmesi muhtemel tüm bu ceza ve tazminatları, gerçekte mağdura, maruz kaldığ1 cinsel saldırı veya şiddet eyleminde masum olduğunun ilanı anlamına gelen bir delil olarak görmek de mümkündür. Aksi takdirde, tecavüz suçunun bedene yönelik zararının ötesinde sebep olduğu psikolojik yıkımın tam olarak tazmin edilmesi pratikte çok mümkün olmayabilir. Bununla birlikte İslam hukuku "Zarar izale olunur"'92 ilkesi gereğince insan ruhunu müteessir edecek olan herhangi bir hâdise ve zararı maddi olsun manevi olsun, kendisine özel

90 İbn Kudâme, el-Muğnî, 8: 44; Tehânevî, Istılâhâti'l-Fünûn ve'l-Ulûm, 1: 813; Ûdeh, etTeşrîu'l-Cinâi'l-İslâmî, 2: 206-207, 281.

91 İbn Kudâme, el-Muğnî, 8: 44; Tehânevî, Istılâhâti'l-Fünûn ve'l-Ulûm, 1: 813; Ûdeh, etTeşrîu'l-Cinâi'l-İslâmî, 2: 206-207, 281.

92 Mecelle madde 20. 
hikmet ve maslahata uygun bir tarzda, tazmin ve tamir etme yönünde tedbirler almıştır.

\subsubsection{Cerrahî Kastrasyon (Hadım) Cezası}

Tecavüzcü, hukûken ve ahlâken koruma altında olan bir organa hakk1 olmayarak ve zorla zarar verdiği için koruma altındaki kendi organina da zarar verilmesinin yolunu açar. Zira fail zor kullanarak mağdurun cinsel uzvuna saldırıda bulunmuştur. Bu suçun karşılı̆̆ı, aynı şekilde kendi cinsel uzvuna yönelik bir yaptırım olmalıdır ki, bu da ancak failin cinsel uzvunun işlevsiz hale getirilmesiyle gerçekleşebilecek bir karşllık gibi görünmektedir. Bu durumu Kur'an'ın genel hukukî ilkelerinden olan "suçun dengi ceza" k3 kuralıyla ilişkilendirmek mümkündür. Zira İslâm'da ceza tespitinde suçlu ile mağdur birlikte mütalaa edilmiş, mümkün olduğu ölçüde suç-ceza dengesi korunmuştur.

Tecavüz suçuna verilecek hadım cezanın psikolojik açıdan suçlu ve mağdur için ne anlama geldiği hususu bir yönüyle psikolojinin derinlemesine irdelemesi gereken bir konu olmakla birlikte, tecavüz neticesinde failin verdiği zararın mağdurda bir ömür boyu etkisini sürdürdüğü gerçeği yaygın olarak bilinmektedir. Suçun bu vasfindan dolayı verilecek ceza da fail üzerinde bir ömür boyu kalıcı olmalıdır. Bu vasfi sağlayacak cezanın cerrâhî kastrasyon (cerrâhî hadım) işlemi olduğu yukarıdaki hukûkî gerekçelerle savunulabilir. Böylece fail cinsel yönden işlediği suçun cezasını cinsel kabiliyetini kaybetmesiyle ödeyecektir. Diğer taraftan mağdur üzerinde bıraktığı maddi-manevi silinmez izleri bir ömür boyu kendi üzerinde taşıyarak işlediği suçun dengi bir ceza ile cezalandırılmıs olacaktır.

\subsubsection{Ceza ve Tazminatla Gözetilen Hukûkî Amaç}

İslam hukukunda hükümler ister küllî ister cüzî şekilde ele alınmış olsun, hükümlerin tamamı can, mal, akıl, şeref, özgürlük gibi insânî ve hukûkî değerlerin korunması için konulmaktadır. İslam Hukuku'nun genel amacı toplumun düzenini korumak ve toplumu meydana getiren fertlerin yararını (salâh) sağlamak suretiyle, toplum yararının devamlılığını

93 “Kim bir kötülük yaparsa onunla (suça göre) cezalandırılır." (en-Nisâ 4/123). 
temin etmektir. ${ }^{94}$ Bu bağlamda tecavüz suçu için belirlenecek cezada da bu hedeflerin gözetilmesi gerekir. ${ }^{95}$

Tecavüz suçu için cerrâhî kastrasyon ve tazminat yaptırımı öngörüldügünde hukukun amacına uygun bazı kazanımların elde edilmesi mümkündür. Bu kapsamda maddi alanda mağdura ödenecek tazminat, en azından mağdurun ekonomik hayatında bir rahatlı̆ga neden olacaktır. Tecavüz suçunun failine verilecek cerrâhî kastrasyon cezası ise gerek mağdur ve gerekse toplum vicdanında önemli bir yaptırım olarak görünecektir. Çünkü tecavüz suçu, sadece mağdur açısından değil, toplum açısından da büyük bir güven kaybına neden olmaktadır. Bundan dolay1 münferit suçların kamu hakkı kapsamında ele alınmasıyla amaçlanan, bahsi geçen bu güven kaybının önüne geçebilmektir. Bu sebeple İslam hukukunda "caydırıcı ceza" (nekâl), modern hukukta "genel önleme" şeklinde isimlendirilen cezada caydırıcılık unsurunun sağlanması için cerrâhî kastrasyon yaptırımının uygulanması, toplum güvenliği açısından da önemlidir.

\section{SONUÇ}

İnsan bedenine karşı işlenen suçların en ağırlarından olan hetk-i 1rz (tecavüz) fiili için İslam hukuk kaynaklarında kullanılan ortak bir kavram bulunmamaktadır. İslam hukukunda tecavüz fiili için iğtisâb, ifdâ, ez-zina bi'l-gahr, müstekrehe ale'z-zinâ, cebr ile tasarruf, gasben abz, cebren fiili sen't, cebren zina, betk-i irz, gibi birden çok nitelemeler mevcuttur. Muhtemelen bu isimlendirmelerde suçun işleniş şekli, suçun toplumda işlenme oranı, suçun oluşumunda üçüncü şahısların suça iştiraki gibi birçok etmen etkili olmuş olabilir. İsimlendirmenin farklı oluşunda tecavüz suçunun Kur'an'da geçen had suçları arasında sayılmamasının etkisi büyüktür. Diğer taraftan tecavüz suçuna maruz kalan kadının

94 Muhammed Tahir İbn Âşûr, Mekasıdu'ş-Şeriati'l-Islâmiyye, (Umman: Dâru'n-Nefâes, ts.), 273 .

95 Konuyla ilgili "Fıkhî Açıdan Nitelikli Cinsel Saldırı (Irza Geçme)" isimli çalışmada, reşit olmayan çocuklara tecavüz suçunun cezası olarak İslam hukukunda öngörülen ta'zir cezasının yeterli olmayacağı, bu tür faillere had cezası uygulanması gerekeceği savunulmaktadır. Müellifin konuyla ilgili içtihadı, hetk-i ırz suçuna yönelik yeni içtihatlara duyulan bireysel ve toplumsal ihtiyacın lüzumunu ifade açısından dikkate değer bir yaklaşımdır. (Bu konuda bk. Sabri Erturhan, "Fıkhî Açıdan Nitelikli Cinsel Saldırı (Irza Geçme)", 54.) 
şikâyette bulunması durumunda kendisinden şahit getirmesinin istenmesi, doğal olarak bu tür suçların gizlenmesi gibi bir netice doğurmaktadır. Tecavüze uğrayan kişinin olay hakkında şahit getirme zorunluluğu, ahlâken ve fiilen zor bir iştir. Dahası, bu suça tanık olan kişinin suça engel olmamasının suça iştirak olarak değerlendirilebileceği endişesi veya suça tanık olduğu halde müdahale etmemesinin şahitlik bağlamında ne anlam ifade edeceğinin de durumu tartışmaya açıktır. Tüm bu sebepleri fikhın konuya gerekli önemi vermemesinin gerekçesi olarak okumak mümkündür.

Güncel bir sorun olan ancak Kur'an'da doğrudan yer almadığ1 için İslam hukukunda mağduru ve toplumu teskin edecek bir ceza tespiti yapılmayan tecavüz suçunun yeniden ele alınmaya ve sebep olduğu sorunlar bağlamında cezasının ne olması gerektiğine ilişkin bir analize ihtiyaç duyulmaktadır. Konunun önemi göz önüne alındığında bu ihtiyaç, tavsiye olmaktan çıkıp zaruret haline gelmiştir.

İslam hukuk mezhepleri hetk-i 1rz (tecavüz) fiilini had gerektiren suçlardan olan zina suçu kapsamında değerlendirdikleri için bu suça had cezasını öngörmüşlerdir. Oysa bu öngörünün, suç-ceza dengesi gözetilmeksizin yapılan bir değerlendirme olduğu düşüncesi ağır basmaktadır. Hadis rivayetlerinin delâletiyle tecavüz suçuna maruz kalan mağdur hakkında dört mezhebin de ortak kanaati, herhangi bir cezaî müeyyide ve sorumluluğunun olmaması yönündedir. Tecavüz suçunun faili hakkında verilecek ceza ve yaptırımlar konusunda ise ihtilaf vardır. Bunlardan mağdur haklarının tazmini için sadece Şâfiîler ve Hanbelîlerin nispeten yeterli diyebileceğimiz yaptırımlanı vardır. Hanefî ve Mâlikîler suç için tayin edilen tazminatın çerçevesini Şâfiî ve Hanbelîlere göre daha sınırle tutmuştur. Hanefîlerin hadlerle tazminatı aynı anda faile yüklememe ilkeleri failin cezasını hafifletirken; tecavüze maruz kalan kişinin uğradığ1 mağduriyeti ağırlaştıran bir sonuç meydana getirmiştir. Bu bağlamda Şâfiî ve Hanbelîlerin tazminat konusundaki tercihlerinin, mağdurun lehine bir yaklaşım olduğu söylenebilir.

Osmanlı kanunnamelerinde tecavüz için öngörülen hadım cezası, şer'î hukukta yer alan ta'zir cezası kapsamında konulmuş cezalar içinde sayılmaktadır. Osmanlı kanunnamelerinde yer alan hadım cezası, Kur'an ceza ilkeleri bağlamında değerlendirildiğinde suç-ceza dengesini gözeten bir müeyyide olduğu rahatlıkla söylenebilir. Bununla birlikte 
kanunnamelerde mağdur lehine tazminat yükümlülüklerinin yer almamış olması bir noksanlık olarak durmaktadır.

Failin vücut bütünlüğünün korunması ve bedensel cezalardan kaçınılması gerektiği yönündeki modern söylem, tecavüz fiiline maruz kalan, suçsuz yere vücut bütünlüğü ve psikolojik dengesi bozulan mağdur lehine tekrar gözden geçirilmelidir. Her iki durumda da vücut bütünlüğü bozuluyorsa, tercih suçsuz olan mağdur için değil, suçlu olan fail için kullanılmalıdır. Böylece cezalarda amaç olarak ortaya konan "genel önleme" ilkesine ulaşmak daha mümkün hale gelebilecektir.

Son tahlilde Kur'an ve hukukun genel ilkeleri açısından tecavüz fiili için cerrâhî kastrasyon ve ağır tazminat yaptırımları öngörülmesinin suç-ceza dengesinin sağlanmasinda mağdur ve toplum lehine daha iyi sonuçlar vereceği kanaatindeyiz. 


\section{KAYNAKÇA}

Abdu'l-Mun'im, Mahmud Abdurrahman. Mu'cem el-Musdalehâtve'l-elfâz̨ı'lFikhiyye. b.y.: Dâru'l-Fazîle, ts.

Âliş, Muhammed. Şerb'uMenbi'l-CelîlAlâMubtasari'l-Allâme Halîl. b.y.: Dâru Mesâdir, tss.

Aydın, Mehmet Akif. "Kanunnameler ve Osmanlı Hukukunun İşleyişindeki Yeri”. Osmanlı Araştırmaları 24 (2004):37-46.

Akgündüz, Ahmed. Mukayeseli İslam ve Osmanle Hukuku Külliyatı. Diyarbakır: Dicle Üniversitesi Hukuk Fakültesi Yayınları,1986.

Akgündüz, Ahmed. "Kanunnâmelerdeki Ceza Hukuku Hükümleri ve Şer'î Tahlilleri”. İslami Arastırmalar Dergisi 12/1 (1999):1-16.

Akgündüz, Ahmed. Osmanl Kanunnâmeleri ve Hukukî Tablilleri: 1. Kitap Osmanl Hukukuna Giris ve Fatih Devri Kanunnameleri. b.y.: Osmanlı Araştırmaları Vakfı Yayınları, ts.

Akgündüz, Ahmed. Osmanl Kanunnâmeleri ve Hukukî Tablilleri: 2. Kitap Bâyezid Devri Kanunnameleri. b.y.: Osmanlı Araştırmaları Vakfı Yayınlar1, ts.

Akgündüz, Ahmed. Osmanl Kanunnâmeleri ve Hukukî Tablilleri: 4. Kitap Kânûnî Devri Kanunnameleri. b.y.: Osmanlı Araştırmaları Vakfı Yayınları, ts.

Artuk, Gökçen, Yenidünya. Cęa Hukuk Genel Hükümler. 5. Bask1, Ankara: Turhan Kitabevi, 2011.

Aydınl, Abdullah. Hadis Istılâblar Sözlügü. İstanbul: İFAV, 2011.

Aydın, Mehmet Akif. "Kanunnameler ve Osmanlı Hukukunun İşleyişindeki Yeri”. Osmanlı Araştırmalan 24 (2004):37-46.

Bilmen, Ömer Nasuhi, Hukukr İslâmiyye ve Istılâhat-ı Fıkhiyye Kâmusu. İstanbul: Bilmen Yayınevi, 1967.

Buhârî, Ebu Abdullah Muhammed b. İsmail. Sabîhu'l-Bubârî (el-Camin'sSahîh). Beyrut: Daru'l-Kütübi'l-İlmiyye, 1998.

Canan, İbrahim. Kütüb-i Sitte Tercüme ve Şerhi. İstanbul: Akçă̆ Yayınları, 1995. 
Dağc1, Şamil. İslâm Cęâa Hukukunda Şahıslara Karşı Müessir Fïller. Ankara: Diyanet İşleri Başkanlı̆̆1 Yayınları, 1996.

“Diyet”. el-Mevsûatü'l-Fıkhìyye. Kuveyt: Vuzâratu'l-Evkâf ve'ş-Şuûni'lİslâmiyye, 1992.

Düzdağ, M. Ertuğrul. Şeyhbülislâm Ebussun̂d Efendi Fetvalar Işı̆̆ında 16. Asır Türk Hayatı. b.y.: Enderun Kitabevi, 1983.

Ebu Dâvud, Süleyman b. Eşas İbn İshak es-Sicistanî. es-Sünen. Beyrut, Dâru'l-Erkâm, 1999.

Ebû Yusuf, Yakup b. İbrahim. Kitâbu'l-Harâc. Beyrut: Dâru'l-Ma'rife, 1979.

Erdoğan, Mehmet, Fıkıһ Terimleri Sö̊lüğü. İstanbul: Rağbet Yayınlan, 1998.

Erdoğan, Suat. Kur'an Sünnet Işı̆ğnda Suc Cez̧a Uygunluğu. Doktora Tezi, İstanbul Üniversitesi, 2014.

Erturhan, Sabri. Fıkhî Açıdan Nitelikli Cinsel Saldırı (Irza Geçme). C.Ü. İlahiyat Fakültesi Dergisi, 2012, cilt. 16, sy. 2, ss. 21-71.

Ekinci, Ekrem Buğra. Osmanl Hukuku. İstanbul: Ar1-Sanat Yayınlar1, 2014.

Fîrûzâbâdi, Mecduddin Muhammed b. Yakup. el-Kamusu'l-Muhit. Misır: Mektebetü Mustafa el-Bâbî Halebî, 1952.

el-Garyânî, Abdurrahmân. el-Fıkhu'l-Mâlikî ve Edilletuhu. Beyrut: Müessesetu'r-Reyyân, 2002.

Gümüş, Musa. "Osmanlı Devleti'nde Kanunlaştırma Hareketleri, İdeolojisi ve Kurumları”. Tarih Okulu 14 (2013):163-200.

İbn Âşûr, Muhammed Tahir. Mekasıdu'ş-Şerîati'l-İslâmìye. Umman: Daru'n-Nefâes, ts.

İbnu'l- Arâbî, Ebû Bekr Muhammed b. Abdillah. Ârratu'l-Ahvezî̉i Şerbi Sabih et-Tirmiq̨. Beyrut: Daru'l-Kütübü'l-İlmiyye, 1995.

İbn Bâbeviyye, Ca'fer Muhammed bin Ali ibn Hüseyin. Men lâ Yahzurbu el-Fakîhbu. Lübnan: Müessesetü’l-A'lemî, ts.

İbn Mâce, Ebu Abdullah Muhammed İbn Yezid el-Kazvinî. es-Sünen. Beyrut: Daru'l-Kütübi'l-İlmiyye, 2004. 
İbn Manzur, Ebu'l-Fadl Cemâluddîn Muhammed. Lisânü'l-Arab. Kâhire: Dâru'l-Meârif, 1119.

el-Kasânî, Ebu Bekr İbn Mes'ûd. Bedâiu's-Sanầ fì Tertîb'i-Şirâî. b.y.: Dâru'l-Hadîs, 1986.

Kayra, Cahit. Osmanli'da Fetvalar ve Günlük Yaşam. b.y.: Boyut Yayınc1lık, 2008.

Koparan, Mehmet Reşat. 5237 sy. TCK'da Cinsel Saldon ve Cinsel Taciz Suclar. Kayseri: 2009. (Erişim: 17 Temmuz 2018, http://www.ceza-bb.adalet.gov.tr/makale/197.pdf)

İbn Kudâme, Ebu Muhammed Abdullah İbn Ahmedibn Muhammed. elMuğni Şerb-u Mubtasaru'l-Harakî. (Riyad: Dâr-u Âlemi'l-Kütüb, 1997.

Mâlik İbn Enes, Muvatta. Dâru'l-Garbi'l-İslâmî. Beyrut: Dâru İhyâi't-Turâs el-Arabî, 1997.

el-Mâverdî, İbn Muhammed ibn Habib. el-Hâvi'l-Kebîr fî Șerh-i Mubtasaru'lMüzenî. Beyrut: Dâru'l-Kütübi'l-İlmiyye, 1994.

el-Mübarekfuri, Ebu'l-Ula Muhammed Abdurrahman b. Abdurrahim. Tubfetu'l-Abvezî̉i Şerbi Câmii't-Tirmį̂î. b.y.: Dâru'l-Fikr, ts.

en-Nevevî, Muhyiddin İbn Şeref. Kitâbu'l-Mecmû' Şerbu'l-Mühezzebli'şŞî̀âż̂. Cidde: Mektebetü'l-İrşâd, ts.

"Osmanlı Hukukunda Tecavüz Suçu”. Belkıs Konan. Erişim: 4 Aralık 2014, http://dergiler.ankara.edu.tr/dergiler/19/1682/17941.pdf.

es-Serahsî, Şemsiddîn. el-Mebsud. Beyrut: Dâru'l-Mârife, ts.

eş-Şeybânî, Muhammed İbn Hasan. Kitâbu'l-Asl (el-Ma'rûf bi'l-Mebsûd). Beyrut: Âlimu'l-Kütüb, 1990.

eş-Şirâzî ebu İshak İbrahim b. Ali b. Yusuf el-Fîruzabâdî. el-Mühezzęe fî Fıkhi'l-İmâmi'ş-Şâfiiyyi. Beyrut: Dâru'l-Kütübi'l-İlmiyye, 1995.

Tirmizî, Ebu İsa Muhammed b. İsa. el-Câmiu's-Sahih. Beyrut: Daru'lMa'rife, 2002.

et-Tûsî, Şeyh Ca’fer Muhammed bin Huseyn İbn Ali. el-Mebsûd fî̀ Fıkbi'lİmâmiyye. Beyrut: Müessese el-Garî, ts. 
Ûdeh, Abdulkadir. et-Teșrî'u'l-Cinâiyyi'l-İslâmî, Beyrut: Müessesetü'rRisâle, 1426.

Yildırım, Adem. Kur'an-Sünnet Issığnda Cezanm Amacı. Doktora Tezi, İstanbul Üniversitesi. İstanbul, 2013.

el-Yemenî, Sâlim el İmrâni'ş-Şâfiî. el-Beyân fi mę̧hebi'l-İmâm eş-Şâfiî. Beyrut: Dâru'l-Minhâc, 2000.

ez-Zürkânî, İbn Ahmed ibn Muhammed. Şerbu'z-Zurkânî Mubtasar-u Seyyidi Halîl. Beyrut: Daru'l-Kütübi'l-İlmiyye, 2002. 